\title{
Consumer perception of sustainable practices in dairy production
}

\author{
Simona Naspetti ${ }^{1}$, Serena Mandolesi ${ }^{1}$, Jeroen Buysse ${ }^{2}$, Terhi Latvala ${ }^{3}$, Phillipa Nicholas ${ }^{4}$, Susanne Padel ${ }^{5}$,
} Ellen J. Van Loo ${ }^{2}$ and Raffaele Zanoli ${ }^{6^{*}}$ (I)

\author{
* Correspondence: zanoli@agrecon. \\ univpm.it \\ ${ }^{6}$ Dipartimento di Scienze Agrarie, \\ Alimentari e Ambientali (D3A), \\ Università Politecnica delle Marche, \\ Via Brecce Bianche, 60131 Ancona, \\ Italy \\ Full list of author information is \\ available at the end of the article
}

\begin{abstract}
Home-grown protein crops as an alternative to soya in dairy cattle meals, as well as other sustainable ethical-based practices, have been proposed to increase the sustainability of dairy production. Data on consumer acceptance of the three novel sustainable production strategies of 'agroforestry', 'prolonged maternal feeding' of young cattle and 'alternative protein source' were collected through an online survey on consumer in six European Union countries: Austria, Belgium, Denmark, Finland, Italy and the UK. Using Chen's extended version of the Theory of Planned Behaviour model, the underlying model hypotheses on the attitudes and intentions of these consumers towards these production practices were tested, to establish the explanatory power of the model in the specific context of novel sustainable production strategies. Furthermore, the influence of gender and consumer ethical choices on their attitudes towards these innovative practices was also tested. These data show that 'prolonged maternal feeding' is the novel production practice that has the highest level of acceptance by consumers in all of these countries, with the least accepted practice as 'alternative protein source'. Unexpectedly, increased availability of home-grown feed, which is grounded on both farmer and societal interests for higher input self-sufficiency and more sustainable production practices, was little appreciated by consumers, although their intentions appear to be dependent on their moral norms.
\end{abstract}

Keywords: Sustainable dairy farming, Animal welfare, Alternative feed, Organic and low-input farming, Consumer acceptance

\section{Introduction}

Innovation in an increasingly globalised dairy market is an essential strategic tool for the dairy industry to achieve a competitive advantage (Jordana 2000; Bishop 2006; Kühne et al. 2010; Almli et al. 2011). However, not all innovation impacts upon consumers in the same way. Product innovation, such as new products or new packaging, are more easily noticed by consumers than, for example, process and system innovations, which are more difficult for the consumer to understand unless they are embedded in specific quality cues (Grunert 2005). Also, innovation in traditional sectors like dairy farming can be a cause of cognitive dissonance, because consumers tend to reject

(c) The Author(s). 2021 Open Access This article is licensed under a Creative Commons Attribution 4.0 International License, which permits use, sharing, adaptation, distribution and reproduction in any medium or format, as long as you give appropriate credit to the original author(s) and the source, provide a link to the Creative Commons licence, and indicate if changes were made. The images or other third party material in this article are included in the article's Creative Commons licence, unless indicated otherwise in a credit line to the material. If material is not included in the article's Creative Commons licence and your intended use is not permitted by statutory regulation or exceeds the permitted use, you will need to obtain permission directly from the copyright holder. To view a copy of this licence, visit http://creativecommons.org/licenses/by/4.0/. 
innovations that can be perceived as altering the authenticity of traditional foods (Almli et al. 2011).

Previous studies have shown that consumers tend to accept processing-technology innovations on the condition that they do not modify the intrinsic attributes of the product (Guerrero et al. 2009). Most studies have investigated the introduction of product innovation (e.g. packaging, labelling, ingredients; Luce et al. 2000; Onwezen and Bartels 2011; Vanhonacker et al. 2013), while fewer studies have concentrated on process innovations, the most 'popular' of which are genetic modifications and nano-technologies (Grunert et al. 2001; Verdurme et al. 2003; Anderson et al. 2006; Sodano et al. 2016), along with organic food (Napolitano et al. 2010a, b; Bjorklund et al. 2014).

The goal of the present study was to examine consumer perceptions of selected innovations in organic and low-input dairy systems. This study forms part of a larger European-funded project that is aimed at enhancing the competitiveness and environmental sustainability of these systems. Among process innovations, we focus here on 'grassroots innovations'. These are defined as 'novel, bottom-up solutions for sustainable development', brought forward by a network of activists and organisations (Hermans et al. 2016). Among these sustainable strategies and solutions, sustainable intensification and agroecology in ruminant farming systems have been proposed as ecologically benign, socially fair and economically viable (Dumont et al. 2018). Similarly, organic and low-input dairy farming has been shown to reduce environmental harm by reducing external input use (Scollan et al. 2017). In general, strategies involving sustainable farming practices have been proposed as process innovations to reduce the impact of dairy farming on the environment and to increase animal welfare and social acceptance of the dairy sector (Padel et al. 2015).

Building on innovations identified in earlier studies of consumer acceptance of farmlevel innovations and innovative practices of dairy farmers (Nicholas et al. 2014; Mandolesi et al. 2015), the present study thus explored consumer preferences towards selected novel sustainable farm-level practices in the dairy supply chain. These innovative practices were designed to address wider issues of sustainability of dairy farming, and they were focused on the following:

- Feeding of ruminants with forage-based diets and home-grown feeds

- Animal management for health and welfare

Specifically, the following three practices were selected after extensive qualitative preliminary research and analysis of stakeholder involvement (Nicholas et al. 2014; Mandolesi et al. 2015). They represent potential solutions to increase the competitiveness and sustainability of the organic and low-input dairy farming supply chain:

- Agroforestry. Integration of animals (i.e. cows, sheep) and trees on the same plot of land

- Prolonged maternal feeding. Calves and lambs are allowed to suckle directly from their mothers (or a foster mother) for the first 3-5 months after they are born.

- Alternative protein source. Use of home-grown protein crops, such as lupins, beans and peas, as animal feed. 


\section{Theoretical framework and hypotheses}

In the relevant literature, all of the proposed models that deal with the acceptance of innovations by consumers derive from the Theory of Planned Behaviour (TPB), as proposed by Ajzen (1991). TPB proposes four predictors:

- 'Intention to behaviour', which has a direct impact on a specific behaviour, and which in turn is inferred by personal attitude, subjective norms and perceived behavioural control

- 'Attitude towards behaviour', the attitude that an individual has to adopt or not adopt a specific behaviour

- 'Subjective norm', the influence that the view of others has on an individual's choices

- 'Perceived behavioural control', factors that might facilitate or constrain the performance of the behaviour

In the food sector, the model has been applied often to the acceptance of controversial food production technologies, such as genetic modification. Bredahl (2001) extended the TPB model to food, particularly with regards to attitude formation. A simplified version of the model was proposed and tested by Chen (2008). 'Attitude towards behaviour' has further antecedents in 'attitude to food produced by the alternative technology' (Chen 2008) and 'attitude towards the technology used in food production' (Bredahl 2001). The present model used the Bredahl construct in the specification of the structural model. This attitude is further measured by the 'perceived risks/benefits' of the new technology.

This theoretical model has been used in numerous studies that have investigated the acceptance of innovation among consumers. This vast empirical literature has focussed on the acceptance of, e.g. organic, fair trade, functional or genetically modified food (e.g. Bredahl 2001; Ozcaglar-toulouse et al. 2006; Vermeir and Verbeke 2007; Arvola et al. 2008; Mazzocchi et al. 2008; O'Connor and White 2010). Of note, in contrast to farmers-who can actually decide to adopt or not to adopt one or more of these innovations-consumers can only express their attitudes as to whether the farmers are using or not using these innovations.

The modifications to the original TPB model used in this study are now described (Fig. 1).

Given the importance of the values that motivate consumers towards the purchase of organic and other 'green' food products (Zanoli and Naspetti 2002; Arvola et al. 2008; Zhu et al. 2013), we modified the Bredahl and Chen extended TPB models and included a further construct: the moral norm (Bredahl 2001; Dean et al. 2008). The core of the adapted model remains with the two variables: attitude and intention. Attitude towards adopting an innovation practice was further measured by two antecedents: risks and benefits. The two 'norms' variables (the influence of 'significant others' expressed by the variable subjective norm, and the influence of strong individual ethical beliefs as measured by the variable moral norm) are direct predictors of intention, separate from attitude and perceived behavioural control.

Based on this theoretical framework, the following hypotheses of consumer adoption of innovations were formulated: 


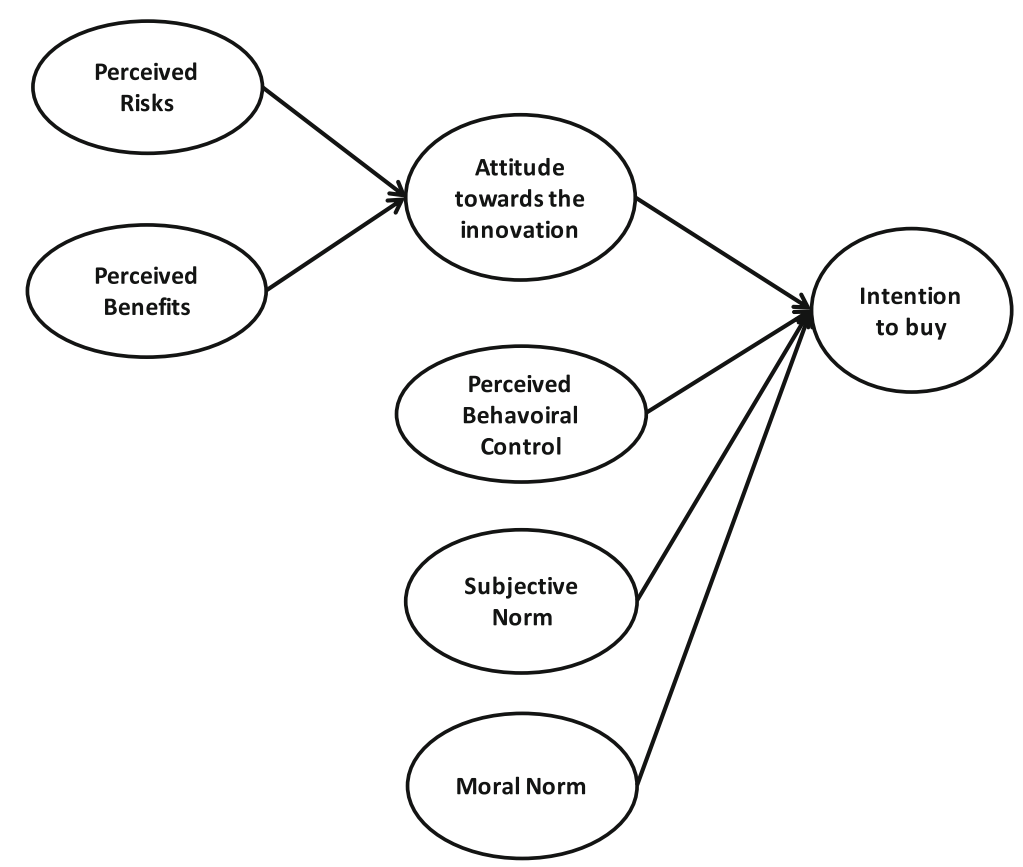

Fig. 1 Consumer innovation acceptance model used in this survey

H1. The attitude of dairy consumers towards dairy products applying one of these innovations is positively associated with their intention to buy the product.

$H 2$. The more that a consumer perceives an innovation as beneficial $(\mathrm{H} 2 \mathrm{a})$ or risky (H2b), the more favourable or unfavourable, respectively, is the consumer attitude towards its adoption.

H3. The more a consumer perceives the influence of social and peer pressure to be favourable towards an innovation, the higher the consumer intention towards buying dairy products where the innovation has been applied.

H4. Consumers with higher moral norm are more likely to have higher intention towards buying dairy products that apply the sustainable innovations.

H5. The attitude towards dairy products that apply a sustainable innovation is more favourable for regular organic consumers.

H6. The attitude towards dairy products that apply an innovation is more favourable for female consumers.

Here, $\mathrm{H} 1$ and $\mathrm{H} 3$ follow directly from the original TPB model. $\mathrm{H} 2$ tests the addition of the two antecedents of the variable attitude: (perceived) benefits and risks. H4 tests the relevance of the additional 'norm' variable to explain the intention to buy. The remaining two hypotheses $(\mathrm{H} 5, \mathrm{H} 6)$ are postulated to empirically test the role of two socio-demographic variables on the attitudes: organic consumption and gender. Previous studies have reported that organic food consumers have been shown to have environmental sustainability among their core motivations (Zanoli and Naspetti 2002; Schösler et al. 2013), while women are more likely to favour ethical, environmental friendly products than men (among others: Magnusson 2001; Ureña et al. 2008; Ha-Brookshire Jung 2011; LópezMosquera 2016). 


\section{Methods}

\section{Data collection and operationalisation of the model}

The data for the evaluation of the theoretical model were collected through a survey sent out to a panel of 6969 consumers of organic and low-input dairy products. These consumers had been recruited by a sub-contracted computer-aided web interview agency across six European countries: Austria (AT), Belgium (BE), Denmark (DK), Finland (FI), Italy (IT) and the United Kingdom (UK; here as England and Wales).

The survey questionnaire was divided into four sections. The first section was the screening section, which was designed to recruit consumers who drank milk or used other dairy products, who were responsible for the household food purchases and who were not employed (as the consumer or someone else in the consumer's household) in the dairy supply chain (e.g. dairy foods industry or food processing) or in a market research company.

The second section included the description of the novel production practices, of agroforestry, prolonged maternal feeding and alternative protein source. Each of these practices was presented to the respondents in a common format, using statements about strengths and weaknesses, and threats and opportunities related to social, technological, environmental, animal welfare, economic and policy arguments. The specific statements that were shown to the consumers are detailed in the Appendix. After reading these three descriptions, the respondents were asked to rank each of the production practices according to their preferences (1st, 2nd, 3rd).

The third section operationalised the constructs included in the model through 19 itemised questions, to allow estimation of the modified TPB model using confirmatory factor analysis (CFA) and structural equation modelling (SEM). The measures used, their definitions, their reference sources and the scale items are given in Table 1. As indicated above, six constructs were included in the model and questionnaire: perceived risks (3 items; Bredahl 2001; Tung et al. 2008), perceived benefits (3 items; Bredahl 2001; Tung et al. 2008), moral norm (3 items; Bredahl 2001; Dean et al. 2008), subjective norm (3 items; O'Connor et al. 2006; Dean et al. 2008; Ottar et al. 2008; Tung et al. 2008), perceived behavioural control (3 items; Bredahl 2001; Saba and Messina 2003; Tung et al. 2008) and attitude towards the production practices (3 items; Bredahl 2001; Cook and Fairweather 2007; Davis et al. 1992; Tung et al. 2008).

All multi-item constructs were measured using a seven-point Likert scale (from 1, strongly disagree, to 7 , strongly agree). One item of the perceived behavioural control construct (v9) was measured using a different seven-point Likert scale (from 1, no control, to 7, complete control).

For parsimony in the administration of the questionnaire, many constructs were just identified; i.e. had only three indicators per latent construct. This is the minimum requirement to identify a CFA model (Kline 2011). Purchase intention was measured as a single item variable (v19). Only one production strategy was proposed in a randomised order to be evaluated in more detail through the 19 itemised questions; all of the items were also randomised, except the one to measure behavioural intention, which was always presented last.

The fourth section of the survey dealt with socioeconomic information (e.g. gender, age, level of education, net income) and questions to collect data on the respondent knowledge and attitudes towards the purchase of organic dairy products. 
Table 1 Definition of the multi-item constructs (original items)

\section{Construct}

Perceived risks (Bredahl 2001; Risk perceptions associated with

Tung et al. 2008)

Perceived benefits (Bredahl 2001; Tung et al. 2008)
Benefit perceptions associated with v4 the adoption of the production practice in the supply chain
Item Item wording

v1 Overall, applying this innovation to dairy production involves considerable risk to the environment, the animals, myself and other people that are important to me.

v2 Overall, applying this innovation to dairy production will prove harmful to the environment, the animals, myself and other people that are important to me.

v3 Overall, applying this innovation to dairy production will prove disadvantageous to the environment, the animals, myself and other people that are important to me.

Overall, applying this innovation to dairy production will prove beneficial to the environment, the animals, myself and other people that are important to me.

v5 Overall, applying this innovation to dairy production will offer great benefits to the environment, the animals, myself and other people that are important to me.

v6 Overall, applying this innovation to dairy production will prove advantageous to the environment, the animals, myself and other people that are important to me.

Perceived behavioural control The perceived ease or difficulty of (PBC) (Bredahl 2001; Saba and buying a product from farms Messina 2003: Tung et al. 2008)

applying the production practice

v7 If dairy products produced on farms utilizing [A. agroforestry; B. alternative protein sources; $\mathrm{C}$. prolonging maternal feeding] were available in the stores nothing would deter me from buying them.

v8 Whether I would buy dairy products produced on farms utilizing [A. agroforestry; B. alternative protein sources; $C$. prolonging maternal feeding] _if available in the stores - is entirely up to me.

v9 How much control do you believe you have over whether or not you purchase dairy products produced on farms utilizing [A. agroforestry; B. alternative protein sources; $C$. prolonging maternal feeding] for your household if available in the stores?

Moral norm (MN) (Bredahl 2001;

A consumer's personal beliefs regarding what is right or wrong v10 Buying dairy products produced on farms utilizing [A. agroforestry; B. alternative protein sources; $C$. prolonging maternal feeding] feels like the morally right thing to do.

V11 Buying dairy products produced

(R) on farms utilizing [A. agroforestry: B. alternative protein sources; $C$. prolonging maternal feeding] goes 
Table 1 Definition of the multi-item constructs (original items) (Continued)

\begin{tabular}{|c|c|c|c|}
\hline Construct & Definition & Item & Item wording \\
\hline & & & against my basic principles. \\
\hline & & v12 & $\begin{array}{l}\text { Buying dairy products produced } \\
\text { on farms utilizing [A. agroforestry; } \\
\text { B. alternative protein sources; } \\
\text { C. prolonging maternal feeding] } \\
\text { would make me feel like a better } \\
\text { person. }\end{array}$ \\
\hline \multirow[t]{3}{*}{$\begin{array}{l}\text { Subjective norm (SN) } \\
\text { (Dean et al. 2008; } \\
\text { O'Connor et al. 2006; } \\
\text { Olsen et al. 2008; } \\
\text { Tung et al. 2008) }\end{array}$} & \multirow[t]{3}{*}{$\begin{array}{l}\text { A consumer's perception of } \\
\text { relevant opinions on whether to } \\
\text { purchase a dairy product from } \\
\text { farms applying the production } \\
\text { practice }\end{array}$} & v13 & $\begin{array}{l}\text { Most people who are important } \\
\text { to me would approve of me } \\
\text { buying dairy products produced } \\
\text { on farms utilizing [A. agroforestry; } \\
\text { B. alternative protein sources; } \\
\text { C. prolonging maternal feeding]. }\end{array}$ \\
\hline & & v14 & $\begin{array}{l}\text { Most people who I value think } \\
\text { that I should buy dairy products } \\
\text { produced on farms utilizing } \\
\text { [A. agroforestry; B. alternative } \\
\text { protein sources; C. prolonging } \\
\text { maternal feeding] if they were } \\
\text { available in the shops. }\end{array}$ \\
\hline & & $\vee 15$ & $\begin{array}{l}\text { My family would encourage me } \\
\text { to buy dairy products produced } \\
\text { on farms utilizing [A. agroforestry; } \\
\text { B. alternative protein sources; } \\
\text { C. prolonging maternal feeding]. }\end{array}$ \\
\hline \multirow{3}{*}{$\begin{array}{l}\text { Attitude (ATU) (Bredahl 2001; } \\
\text { Cook and Fairweather 2007; } \\
\text { Davis et al. 1992; } \\
\text { Tung et al. 2008) }\end{array}$} & \multirow{3}{*}{$\begin{array}{l}\text { Consumer positive or negative } \\
\text { feeling associated with the } \\
\text { adoption of the production } \\
\text { practice }\end{array}$} & v16 & $\begin{array}{l}\text { The introduction of such innovation } \\
\text { in the supply chain would be } \\
\text { acceptable for me. }\end{array}$ \\
\hline & & v17 & $\begin{array}{l}\text { All things considered introducing } \\
\text { such an innovation in the dairy } \\
\text { supply chain is not a good idea. }\end{array}$ \\
\hline & & v18 & $\begin{array}{l}\text { Applying such an innovation in } \\
\text { the dairy supply chain would be } \\
\text { wise. }\end{array}$ \\
\hline $\begin{array}{l}\text { Intention to purchase } \\
\text { (Venkatesh et al. 2003) }\end{array}$ & $\begin{array}{l}\text { Consumer intention to purchase a } \\
\text { dairy product from farms applying } \\
\text { the production practice }\end{array}$ & v19 & $\begin{array}{l}\text { All things considered, if dairy } \\
\text { products produced on farms } \\
\text { utilizing [A. agroforestry; } \\
\text { B. alternative protein sources; } \\
\text { c. prolonging maternal feeding] } \\
\text { were available in the shops, } \\
\text { I would definitely buy them. }\end{array}$ \\
\hline
\end{tabular}

$(R)$ reverse ranking

The questionnaire used in the survey was written in English and translated into the other languages by mother-tongue researchers. Back-translation was used to check that the original sense of each question was not lost in the translations. Extensive crosschecking, editing and pre-testing was conducted before administering the survey. After data collection, eligibility and consistency checks were performed, and 5497 consumer responses were retained.

The eligibility criteria for the sample were the following:

- Being responsible for the family food shopping

- Not being employed (the consumer or someone else in the consumer's household) in one of the following professions: dairy food industry or food processing, or a market research company 
- Buying milk and other dairy products for personal consumption and/or for other members of the consumer's household

According to these criteria, 778 respondents were deemed ineligible. Also, 668 'speeders' were excluded from the final sample (i.e. those who used less than $4.5 \mathrm{~min}$ to complete the survey).

\section{Data analysis}

Estimation of the CFA and SEM models was performed using a robust (Satorra-Bentler) maximum likelihood estimator (Satorra and Bentler 1994; Hancock and Mueller 2013) using Mplus 8 (Muthén and Muthén 2017). We conducted a post hoc analysis to perform further model invariance tests finalised to latent means difference testing:

- Across non-organic, occasional and regular organic consumers (levels of organic experience)

- Across genders (male vs. female)

In addition, latent means difference tests were carried out to check whether for each alternative production practice there were different mean attitudes across countries.

\section{Results}

\section{Sample socio-demographics}

The majority of the respondents included (i.e. consumers) had attained secondary education, with some differences across the countries. A comparison with Eurostat (2014a) data showed that the consumers with tertiary education were over-represented in this sample, which was particularly evident for Belgium and Italy ${ }^{1}$. The full sample description is given in Table 2.

The majority of the consumers' households in the overall samples (59\%) had a net income below the official average monthly wage for the selected countries (about 2366 euros per month). The median wage was 1500-2500 euros per month. According to the country means, $32.8 \%$ of households received on average 2269 euros per month, with Italy as the lowest (1983 euros per month; standard deviation 0.9) and Denmark the highest (2619 euros per month; standard deviation 1.1). The inequality in income distribution was measured by the Gini index (Fig. 2). These data showed that the household monthly net income distribution for this sample was a little lower than the official statistics from Eurostat (2014b).

The mean number of people in each of the consumers' households was a little over two, with the exception of Italy, which exceeded three people. The majority of these households were made up of couples (36.7\%).

With respect to the consumer experience with organic products, as measured by the proxy variable 'self-reported frequency of purchase', they were divided into three groups: non-organic consumers (consuming organic products less than once per month), occasional organic consumers (consuming organic products at least once or

\footnotetext{
${ }^{1}$ For the mean of the five countries studied, Eurostat (2014a) reports the following educational attainment levels: less than secondary education, $25.7 \%$; secondary education, $45.1 \%$; and tertiary education, $29.3 \%$.
} 
Table 2 Description of the sample

\begin{tabular}{|c|c|c|c|c|c|c|c|}
\hline \multirow[t]{2}{*}{ Group } & \multicolumn{6}{|c|}{ Country } & \multirow[t]{2}{*}{ Total } \\
\hline & $\overline{\mathrm{AT}}$ & $\mathrm{BE}$ & DK & $\mathrm{FI}$ & IT & UK & \\
\hline Valid respondents $(N)$ & 905 & 901 & 893 & 904 & 985 & 909 & 5497 \\
\hline \multicolumn{8}{|l|}{ Gender (\%) } \\
\hline Male & 41.4 & 43.1 & 47.8 & 45.9 & 31.8 & 40.4 & 41.6 \\
\hline Female & 58.6 & 56.9 & 52.2 & 54.1 & 68.2 & 59.6 & 58.4 \\
\hline \multicolumn{8}{|l|}{ Age range, in years (\%) } \\
\hline $18-29$ & 25.1 & 18.8 & 16.5 & 21.5 & 26.8 & 8.4 & 19.6 \\
\hline $30-45$ & 37.1 & 29.6 & 28.8 & 29.0 & 50.0 & 25.9 & 33.6 \\
\hline $46-65$ & 34.0 & 44.7 & 43.9 & 39.4 & 21.4 & 49.4 & 38.5 \\
\hline Over 65 & 3.8 & 7.0 & 10.9 & 10.2 & 1.7 & 16.4 & 8.2 \\
\hline \multicolumn{8}{|l|}{ Household monthly net income, in Euro (\%) } \\
\hline Less than 1500 & 27.0 & 20.1 & 18.6 & 28.2 & 30.1 & 30.6 & 25.8 \\
\hline $1501-2500$ & 36.6 & 34.7 & 27.5 & 24.0 & 41.2 & 31.8 & 32.8 \\
\hline $2501-3500$ & 25.2 & 28.9 & 22.5 & 23.7 & 21.5 & 19.6 & 23.5 \\
\hline Over 3500 & 11.3 & 16.3 & 31.4 & 24.1 & 7.2 & 18.0 & 17.9 \\
\hline \multicolumn{8}{|l|}{ Years of formal education (\%) } \\
\hline Less than secondary education (up to 10 years) & 45.5 & 17.4 & 30.6 & 15.0 & 1.0 & 35.5 & 23.8 \\
\hline Secondary education (12-13 years) & 36.4 & 34.9 & 37.4 & 53.1 & 51.8 & 20.4 & 39.1 \\
\hline Tertiary education (more than 13 years) & 18.1 & 47.7 & 32.0 & 31.9 & 47.2 & 44.1 & 37.0 \\
\hline \multicolumn{8}{|l|}{ Experience with organic products (\%) } \\
\hline Non-organic consumers & 24.1 & 44.9 & 40.5 & 62.8 & 25.2 & 62.1 & 43.0 \\
\hline Occasional consumers & 30.1 & 27.5 & 28.1 & 22.9 & 25.0 & 18.8 & 25.2 \\
\hline Regular consumers & 45.8 & 27.6 & 31.4 & 14.3 & 50.8 & 19.1 & 31.8 \\
\hline
\end{tabular}

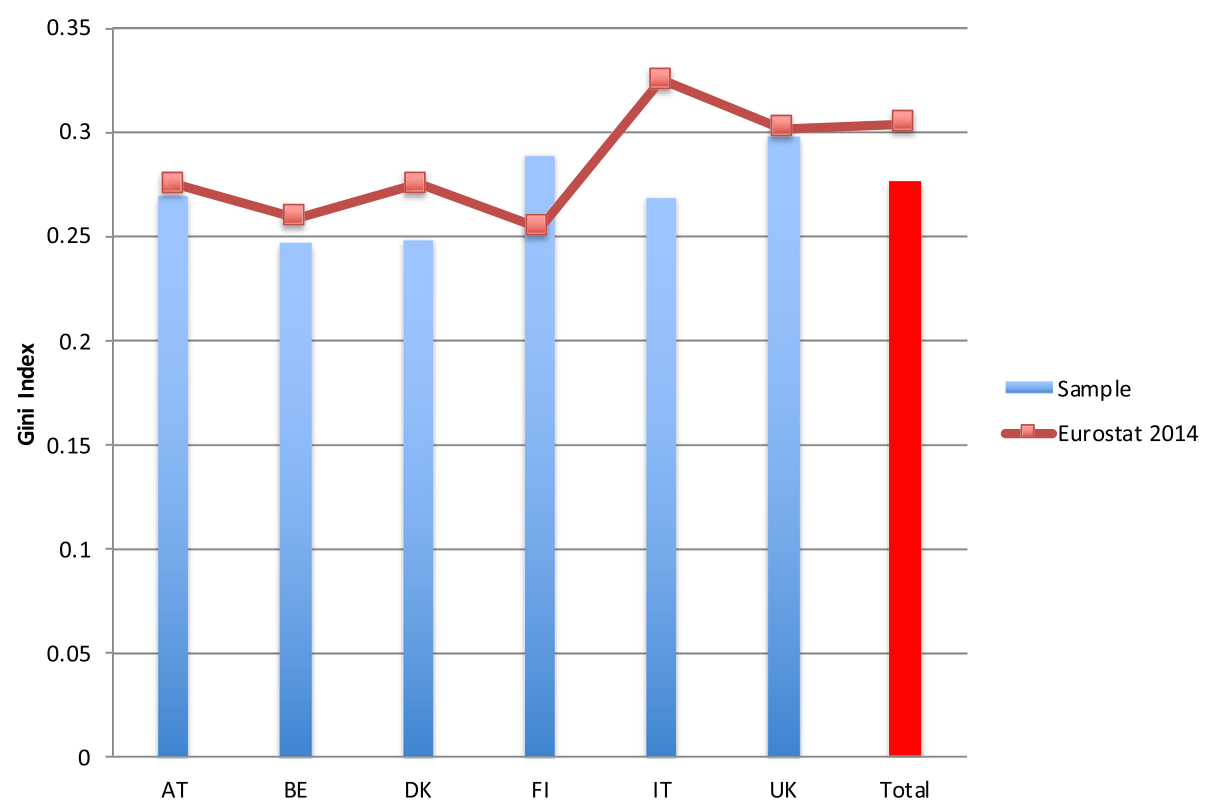

Fig. 2 Gini index for net income per country 
twice per month) and regular organic consumers (consuming organic products once or more per week). Organic self-reported regular consumers represented about one third of the overall sample, occasional consumers one fourth, and the remaining $43 \%$ were non-organic consumers.

\section{Evaluation of the measurement model and assessment of cross-culture validity}

Cross-culture validity refers to the measurement invariance across the different nation groups and reflects 'the extent to which the data collected by the same measurement instrument are comparable across different cultural environments' (Bredahl 2001).

Confirmatory factor analysis was conducted on multi-item scales for each practice across each country, such as attitude, subjective norm, moral norm, perceived behavioural control, perceived benefits and perceived risks. Given that the multi-item latent variables were measured by ordered categorical indicators, inspection of the data suggested a robust estimation method for departure from normality. Following Finney and Di Stefano (in Hancock and Mueller 2013), we used Satorra-Bentler scaling of the variables with maximum likelihood estimation.

Estimation of the CFA models for each practice and cross-country validation resulted in the exclusion of perceived risks and perceived behavioural control from the final measurement model (they also showed poor reliability; i.e. Cronbach's alpha $<0.63$; King and He 2006). The following items were also excluded from the analysis: v11 (in moral norm) and v13 (in subjective norm). All of the measurement statistics for each novel production strategy are given in Table 3, 4 and 5, while the tests of the validity of the CFA models are given in Table 6.

Table 3 Agroforestry: measurement properties of the multi-item constructs $(N=1829)$

\begin{tabular}{|c|c|c|c|c|c|c|}
\hline Construct & $\begin{array}{l}\text { Standard } \\
\text { loading } \\
(>0.7)\end{array}$ & Mean & S.D. & $\begin{array}{l}\text { Cronbach's } \\
\text { alpha }(>0.7)\end{array}$ & $\begin{array}{l}\text { Composite } \\
\text { reliability (rho) } \\
(>0.6)\end{array}$ & $\begin{array}{l}\text { Average variance } \\
\text { extracted }(>0.5)\end{array}$ \\
\hline Perceived risks ${ }^{a}$ & & & & .84 & .85 & .65 \\
\hline $\begin{array}{l}\text { Perceived behavioural control } \\
(\mathrm{PBC})^{\mathrm{a}}\end{array}$ & & & & $.38^{\mathrm{a}}$ & .68 & .44 \\
\hline Perceived benefits & & & & .90 & .89 & .73 \\
\hline v4 & $0.85^{*}$ & 5.21 & 1.19 & & & \\
\hline v5 & $0.86^{*}$ & 5.13 & 1.21 & & & \\
\hline v6 & $0.85^{*}$ & 5.19 & 1.20 & & & \\
\hline Moral norm (MN) & & & & .79 & .78 & .64 \\
\hline v10 & $0.85^{*}$ & 5.13 & 1.22 & & & \\
\hline v12 & $0.75^{*}$ & 4.62 & 1.35 & & & \\
\hline Subjective norm (SN) & & & & .80 & .71 & .55 \\
\hline v14 & $0.70^{*}$ & 4.28 & 1.35 & & & \\
\hline v15 & $0.78^{*}$ & 4.39 & 1.41 & & & \\
\hline Attitude (ATU) & & & & .74 & .76 & .52 \\
\hline v16 & $0.80^{*}$ & 5.41 & 1.26 & & & \\
\hline v17 & $0.47^{*}$ & 4.89 & 1.60 & & & \\
\hline v18 & $0.84^{*}$ & 5.16 & 1.22 & & & \\
\hline
\end{tabular}


Table 4 Prolonged maternal feeding: Measurement properties of the multi-item constructs $(N=1852)$

\begin{tabular}{|c|c|c|c|c|c|c|}
\hline Construct & $\begin{array}{l}\text { Standard } \\
\text { loading } \\
(>0.7)\end{array}$ & Mean & S.D. & $\begin{array}{l}\text { Cronbach's alpha } \\
(>0.7)\end{array}$ & $\begin{array}{l}\text { Composite } \\
\text { reliability } \\
\text { (rho) }(>0.6)\end{array}$ & $\begin{array}{l}\text { Average variance } \\
\text { extracted }(>0.5)\end{array}$ \\
\hline Perceived risks ${ }^{a}$ & & & & .84 & .85 & .65 \\
\hline $\begin{array}{l}\text { Perceived behavioural } \\
\text { control (PBC) }\end{array}$ & & & & .43 & .68 & .44 \\
\hline Perceived benefits & & & & .89 & .90 & .75 \\
\hline v4 & $0.87^{*}$ & 5.04 & 1.30 & & & \\
\hline v5 & $0.86^{*}$ & 4.98 & 1.33 & & & \\
\hline v6 & $0.87^{*}$ & 4.98 & 1.32 & & & \\
\hline Moral norm (MN) & & & & .78 & .79 & .66 \\
\hline v10 & $0.85^{*}$ & 5.09 & 1.38 & & & \\
\hline v12 & $0.77^{*}$ & 4.63 & 1.46 & & & \\
\hline Subjective norm (SN) & & & & .71 & .79 & .66 \\
\hline v14 & $0.78^{*}$ & 4.24 & 1.47 & & & \\
\hline v15 & $0.84^{*}$ & 4.32 & 1.51 & & & \\
\hline Attitude (ATU) & & & & .72 & .77 & .54 \\
\hline v16 & $0.79 *$ & 5.31 & 1.30 & & & \\
\hline v17 & $0.49^{*}$ & 4.75 & 1.65 & & & \\
\hline v18 & $0.87^{*}$ & 5.02 & 1.29 & & & \\
\hline
\end{tabular}

Table 5 Alternative protein source: measurement properties of the multi-item constructs $(N=1816)$

\begin{tabular}{|c|c|c|c|c|c|c|}
\hline Construct & $\begin{array}{l}\text { Standard } \\
\text { loading } \\
(>0.7)\end{array}$ & Mean & S.D. & $\begin{array}{l}\text { Cronbach's } \\
\text { alpha }(>0.7)\end{array}$ & $\begin{array}{l}\text { Composite } \\
\text { reliability } \\
\text { (rho) }(>0.6)\end{array}$ & $\begin{array}{l}\text { Average variance } \\
\text { extracted }(>0.5)\end{array}$ \\
\hline Perceived risks ${ }^{a}$ & & & & .87 & .87 & .68 \\
\hline Perceived behavioural control (PBC) ${ }^{a}$ & & & & .34 & .33 & .19 \\
\hline Perceived benefits & & & & .90 & .89 & .73 \\
\hline v4 & $0.86^{*}$ & 4.65 & 1.33 & & & \\
\hline v5 & $0.84^{*}$ & 4.64 & 1.30 & & & \\
\hline v6 & $0.86^{*}$ & 4.68 & 1.30 & & & \\
\hline Moral norm (MN) & & & & .78 & .78 & .63 \\
\hline v10 & $0.83^{*}$ & 4.61 & 1.38 & & & \\
\hline $\mathrm{v} 12$ & $0.76^{*}$ & 4.09 & 1.43 & & & \\
\hline Subjective norm (SN) & & & & .74 & .74 & .59 \\
\hline v14 & $0.78^{*}$ & 3.88 & 1.39 & & & \\
\hline v15 & $0.76^{*}$ & 3.91 & 1.49 & & & \\
\hline Attitude (ATU) & & & & .78 & .80 & .57 \\
\hline v16 & $0.80^{*}$ & 4.92 & 1.35 & & & \\
\hline v17 & $0.55^{*}$ & 4.41 & 1.58 & & & \\
\hline v18 & $0.88^{*}$ & 4.70 & 1.32 & & & \\
\hline
\end{tabular}

${ }^{*} p<.001$

${ }^{a}$ Constructs not included in the final measurement model (N.B. only retained item loadings are included) 
Table 6 Testing the factorial validity of the confirmatory factor analysis models

\begin{tabular}{|c|c|c|c|c|c|c|c|}
\hline \multirow[t]{2}{*}{ Construct } & \multicolumn{7}{|c|}{ Items included in each model } \\
\hline & Full model & Model 0 & Model 1 & Model 2 & Model 2 AF & Model 2 MF & Model 2 PS \\
\hline \multicolumn{8}{|l|}{ Perceived risks ${ }^{\mathrm{b}}$} \\
\hline v1 & $\checkmark$ & $\checkmark$ & $\checkmark$ & & & & \\
\hline v2 & $\checkmark$ & $\checkmark$ & $\checkmark$ & & & & \\
\hline v3 & $\checkmark$ & $\checkmark$ & $\checkmark$ & & & & \\
\hline \multicolumn{8}{|l|}{ Perceived benefits } \\
\hline v4 & $\checkmark$ & $\checkmark$ & $\checkmark$ & $\checkmark$ & $\checkmark$ & $\checkmark$ & $\checkmark$ \\
\hline v5 & $\checkmark$ & $\checkmark$ & $\checkmark$ & $\checkmark$ & $\checkmark$ & $\checkmark$ & $\checkmark$ \\
\hline v6 & $\checkmark$ & $\checkmark$ & $\checkmark$ & $\checkmark$ & $\checkmark$ & $\checkmark$ & $\checkmark$ \\
\hline \multicolumn{8}{|c|}{ Perceived behavioural control $(\mathrm{PBC})^{\mathrm{b}}$} \\
\hline v7 & $\checkmark$ & $\checkmark$ & & & & & \\
\hline v8 & $\checkmark$ & $\checkmark$ & & & & & \\
\hline v9 & $\checkmark$ & $\checkmark$ & & & & & \\
\hline \multicolumn{8}{|l|}{ Moral norm (MN) } \\
\hline v10 & $\checkmark$ & $\checkmark$ & $\checkmark$ & $\checkmark$ & $\checkmark$ & $\checkmark$ & $\checkmark$ \\
\hline v11 & $\checkmark$ & & & & & & \\
\hline $\mathrm{v} 12$ & $\checkmark$ & $\checkmark$ & $\checkmark$ & $\checkmark$ & $\checkmark$ & $\checkmark$ & $\checkmark$ \\
\hline \multicolumn{8}{|l|}{ Subjective norm (SN) } \\
\hline v13 & $\checkmark$ & & & & & & \\
\hline v14 & $\checkmark$ & $\checkmark$ & $\checkmark$ & $\checkmark$ & $\checkmark$ & $\checkmark$ & $\checkmark$ \\
\hline v15 & $\checkmark$ & $\checkmark$ & $\checkmark$ & $\checkmark$ & $\checkmark$ & $\checkmark$ & $\checkmark$ \\
\hline \multicolumn{8}{|l|}{ Attitude (ATU) } \\
\hline v16 & $\checkmark$ & $\checkmark$ & $\checkmark$ & $\checkmark$ & $\checkmark$ & $\checkmark$ & $\checkmark$ \\
\hline v17 & $\checkmark$ & $\checkmark$ & $\checkmark$ & $\checkmark$ & $\checkmark$ & $\checkmark$ & $\checkmark$ \\
\hline v18 & $\checkmark$ & $\checkmark$ & $\checkmark$ & & & & \\
\hline \multicolumn{8}{|l|}{ Model fit } \\
\hline RMSEA & $N A^{a}$ & 0.052 & 0.057 & 0.034 & 0.036 & 0.042 & 0.035 \\
\hline$P($ RMSEA $) \leq 0.05$ & $N A^{a}$ & 0.08 & 0.00 & 1.00 & 0.998 & 0.948 & 0.999 \\
\hline $\mathrm{CFI}$ & $N A^{a}$ & 0.963 & 0.967 & 0.993 & 0.992 & 0.988 & 0.992 \\
\hline SRMR & $N A^{a}$ & 0.052 & 0.056 & 0.019 & 0.021 & 0.023 & 0.020 \\
\hline
\end{tabular}

RMSEA root mean square error of approximation, $P(R M S E A) \leq 0.05 p$ value of the close-fit hypothesis, CFI Comparative Fit Index, SRMR standardised root mean square residual

${ }^{a}$ The latent variable covariance matrix is not positive definite

${ }^{b}$ Constructs not included in the final measurement model

These results were not surprising. Perceived behavioural control is rarely significant in most of the reviewed literature. The exclusion of perceived risks from the final measurement model was also not unexpected, as consumers do not perceive any significant risks should the farmers adopt any of the tested practices.

Tables 7, 8 and 9 report the results of the measurement invariance tests for each production practice. Multiple-sample CFA were run across the various countries: chisquare difference tests are reported for configural vs. metric and metric vs. scalar measurement invariance. These invariance tests are affected by the overall sample size (very large here), which led to rejection of the invariance in most cases. Therefore, following Cheung and Rensvold (2002) and Meade et al. (2008), we also report the Bentler Comparative Fit Index $(\mathrm{CFI})$ : changes in CFI $(\triangle \mathrm{CFI}) \leq 0.01$ indicate that the null hypothesis 
Table 7 Tests of cross-country measurement invariance-agroforestry

\begin{tabular}{llllllll}
\hline Model & $\boldsymbol{X}^{2}$ & DF & Correction factor & Corrected $\boldsymbol{X}^{2}$ & $\boldsymbol{P}$ value & CFI & $\boldsymbol{\Delta \text { CFI }}$ \\
\hline Configural (C) & 261.490 & 162 & 1.513 & & & 0.987 & \\
Metric (M) & 307.056 & 192 & 1.475 & & & 0.985 & 0.002 \\
Scalar (S) & 476.698 & 222 & 1.413 & & & 0.966 & 0.019 \\
Diff. C vs M & 45.116 & 30 & 1.270 & 45.104 & 0.038 & & \\
Diff. M vs S & 218.114 & 30 & 1.016 & 217.149 & 0.000 & \\
\hline
\end{tabular}

of invariance should not be rejected. Agroforestry showed metric invariance, meaning that there were equal factor loadings across countries. Both prolonged maternal feeding and alternative protein source, on the other hand, showed the stronger form of crosscultural validity (scalar invariance), which means that the factor loadings and intercepts/thresholds were equal across the countries.

Convergent validity is supported by the high and significant standardised loadings for the measures (Anderson and Gerbing 1988). Multiple-group measurement invariance was also tested for two relevant socio-demographic variables, experience (non-organic vs. occasional and regular consumers) and gender (male vs. female), to determine whether differences in the latent means could be explored for these cases. Again, exploration of the $\triangle \mathrm{CFI}$ indicated that neither the null hypotheses of metric nor scalar invariance should be rejected (results not shown).

Finally, measurement invariance was also tested for the pooled country data across the three production practices, to determine whether it was possible to proceed to test a pooled structural equation model across both countries and innovations. As metric invariance was not rejected for all of the production practices, we can report the results of the pooled CFA models (covering AT, BE, DK, FI, IT, UK), all of which showed close fits (Table 10). In the pooled CFA models, all of the loadings of variables were significant and above the 0.50 threshold.

\section{Ranking of innovative production strategies}

Respondents were asked to read a brief description of each of the novel production strategies and then to rank these in their order of preference according to their personal point of view. Figures 3, 4 and 5 report the country differences for each novel production strategy. These pooled results show that the production strategy 'prolonged maternal feeding' was ranked first by $42.1 \%$ of the consumers and second by $31.8 \%$, for a total of 73.7\%. 'Agroforestry' was a little less favoured, as it was ranked first by a third of the consumers (33.3\%) and was ranked second by another $38.2 \%$, for a total of

Table 8 Tests of cross-country measurement invariance-prolonged maternal feeding

\begin{tabular}{llllllll}
\hline Model & $\boldsymbol{x}^{\mathbf{2}}$ & DF & Correction factor & Corrected $\boldsymbol{x}^{2}$ & $\boldsymbol{P}$ value & CFI & $\boldsymbol{\Delta \text { CFI }}$ \\
\hline Configural (C) & 247.698 & 174 & 1.541 & & & 0.991 & \\
Metric (M) & 295.776 & 204 & 1.480 & & & 0.989 & 0.002 \\
Scalar (S) & 391.889 & 234 & 1.419 & & 0.981 & 0.008 \\
Diff. C vs M & 48.078 & 30 & 1.125 & 49.769 & 0.013 & & \\
Diff. M vs S & 96.113 & 30 & 1.004 & 117.851 & 0.000 & & \\
\hline
\end{tabular}


Table 9 Tests of cross-country measurement invariance-alternative protein source.

\begin{tabular}{llllllll}
\hline Model & $\boldsymbol{x}^{\mathbf{2}}$ & DF & Correction factor & Corrected $\boldsymbol{x}^{\mathbf{2}}$ & $\boldsymbol{P}$ value & CFI & $\boldsymbol{\Delta \text { CFI }}$ \\
\hline Configural (C) & 234.113 & 162 & 1.501 & & & 0.991 & \\
Metric (M) & 280.778 & 192 & 1.435 & & & 0.989 & 0.002 \\
Scalar (S) & 392.522 & 222 & 1.376 & & 0.980 & 0.009 \\
Diff. C vs M & 46.665 & 30 & 1.078 & 47.759 & 0.021 & & \\
Diff. M vs S & 111.744 & 30 & 1.002 & 137.107 & 0.000 & \\
\hline
\end{tabular}

71.5\%. Although there were differences across the countries, 'alternative protein source' was the least preferred strategy by the respondents: only $24.6 \%$ of them ranked it first.

\section{Attitude towards behaviour and intention to purchase}

The consumer attitude towards adopting dairy food products from farms that used each of the alternative production practices was measured according to the three items described above and given in Table 1. By inspecting the mean ratings (Table 11) for all of the countries taken together, we can conclude that attitude towards behaviour was significantly higher for dairy products produced using prolonged maternal feeding than for agroforestry, while the practice of alternative protein source had a significantly lower mean rating than these other two.

The intention to purchase products that were produced using these three practices was measured according to a single seven-point bipolar item (i.e. extremely likely to extremely unlikely). As shown in Figs. 6, 7 and 8, for all three of the practices, the modal category was 'somewhat likely' (i.e. a value of 5 in the Likert scale adopted), although for alternative protein sources the category 'neither likely nor unlikely' was chosen with almost the same frequency (Fig. 8).

Through inspection of the mean ratings for all of the countries taken together (Table 12), we can conclude that intention to purchase was a little higher for dairy products produced using agroforestry than prolonged maternal feeding. Consistent with the overall observed pattern of rankings, the practice of alternative protein source had the lowest mean rating here, and it followed a more skewed distribution.

\section{Results of the structural equation model}

For the analysis of the structural equation model, the full sample of consumers was used (i.e. 5497 complete responses). Each consumer rated only one single practice. As these data showed measurement invariance, we could proceed by estimating one pooled cross-country model for each alternative production practice. The estimated structural equation models for each alternative production practice are presented in

Table 10 Pooled confirmatory factor analysis model fit indices

\begin{tabular}{llllllllll}
\hline & $\boldsymbol{x}^{\mathbf{2}}$ & df & $\boldsymbol{P}$ value & \multicolumn{2}{l}{ RMSEA } & \multicolumn{2}{l}{ SRMS } & CFI \\
\cline { 5 - 8 } & & & & Value & $\mathbf{9 0 \%} \mathbf{C l}$ & Probability $(\leq \mathbf{0 . 0 5})$ & & \\
\hline Agroforestry & 90.74 & 27 & $<0.001$ & 0.036 & $0.28-0.44$ & 0.998 & 0.021 & 0.992 \\
Prolonged maternal feeding & 114.10 & 27 & $<0.001$ & 0.042 & $0.34-0.05$ & 0.948 & 0.023 & 0.988 \\
Alternative protein source & 86.74 & 27 & $<0.001$ & 0.035 & $0.27-0.43$ & 0.999 & 0.020 & 0.992 \\
\hline
\end{tabular}




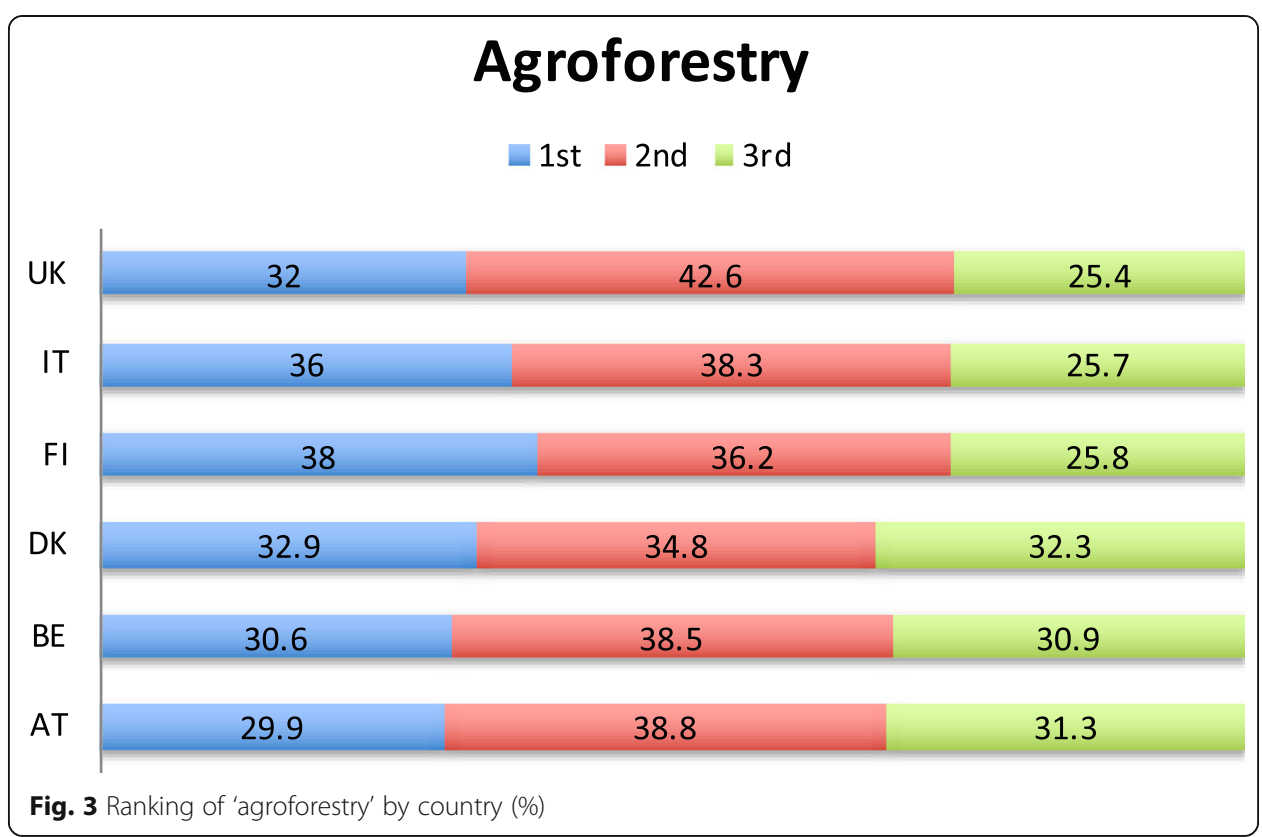

Figs. 6, 7 and 8. All three of the models showed close fits with the observed data, as reported in Table 13.

Inspection of the models made it clear that while the three production practices shared an invariant measurement part, they had a non-invariant structural part that distinguished each practice from each of the others in terms of how the consumer attitudes and purchase intentions were formed. First of all, in the agroforestry model, the path moral norm to intention to purchase was not significant (and therefore could be deleted). Intention is explained by attitude and, to a lower extent, by subjective norm. This was specific to agroforestry, as the other two production practices appeared to have a more similar structural part in both the formation of consumer attitude towards

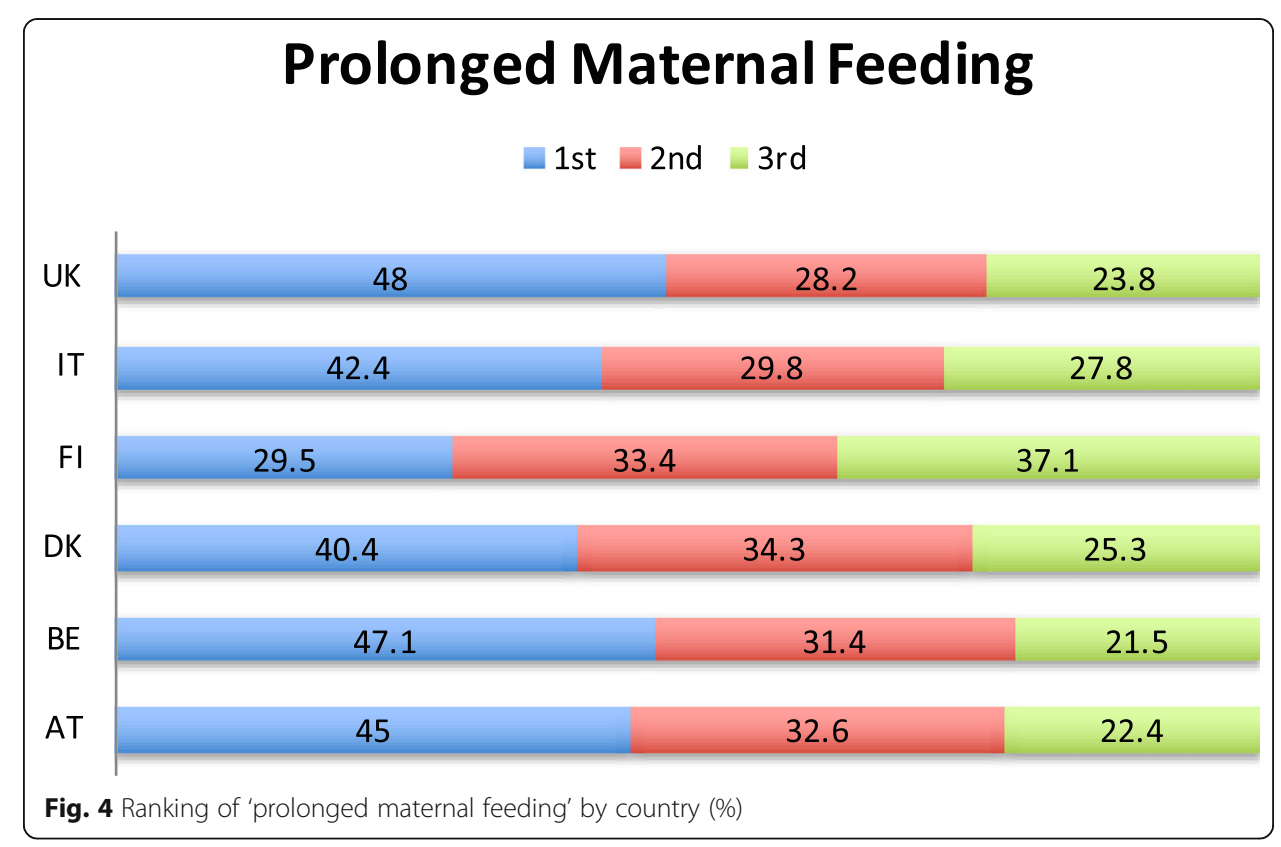




\begin{tabular}{|c|c|c|c|}
\hline & \multicolumn{3}{|c|}{ Alternative Protein Source } \\
\hline & & $\square$ 1st $\square$ 2nd & $3 r d$ \\
\hline UK & 20 & 29.2 & 50.8 \\
\hline IT & 21.5 & 31.9 & 46.6 \\
\hline $\mathrm{FI}$ & 32.4 & 30.4 & 37.2 \\
\hline DK & 26.7 & 30.9 & 42.4 \\
\hline $\mathrm{BE}$ & 22.3 & 30.1 & 47.6 \\
\hline AT & 25.1 & 28.6 & 46.3 \\
\hline
\end{tabular}

the proposed production practices and in the formation of the intention to purchase. In all cases, perceived benefits were highly correlated with attitude, which in turn was the most relevant factor that influenced intention to purchase for all of the practices except for alternative protein sources. For this last innovative practice, consumer attitude was much lower, and it basically had the same influence on intention to buy as moral norm. Moral norm appeared to be a more relevant antecedent of intention to purchase than subjective norm if agroforestry was excluded, where it was not a significant predictor of intention, as previously shown (Figs. 9, 10 and 11).

\section{Post hoc analysis}

Full metric invariance held across both levels of organic experience and gender and across countries. Therefore, we proceeded in the testing for latent means differences in attitude.

Table 14 gives the results for the means difference testing of attitude towards each of these innovative production practices across gender and levels of experience. The results in terms of attitude towards the three alternative innovative production practices show that females are more favourable (i.e. exhibit higher values for attitude) thane men. Organic consumers (both regular and occasional) are more favourable than nonorganic consumers. These results will be discussed in details below, in relation to their respective hypotheses.

Table 11 Descriptive statistics for attitude towards behaviour (all countries)

\begin{tabular}{lll}
\hline Model & Mean & Standard deviation \\
\hline Agroforestry & $4.73^{\mathrm{a}}$ & 1.08 \\
Prolonged maternal feeding & $4.83^{\mathrm{b}}$ & 0.99 \\
Alternative protein sources & $4.36^{\mathrm{c}}$ & 1.06 \\
\hline
\end{tabular}

Values with different superscript letters are significantly different ( $p>0.01$; Bonferroni adjusted) 


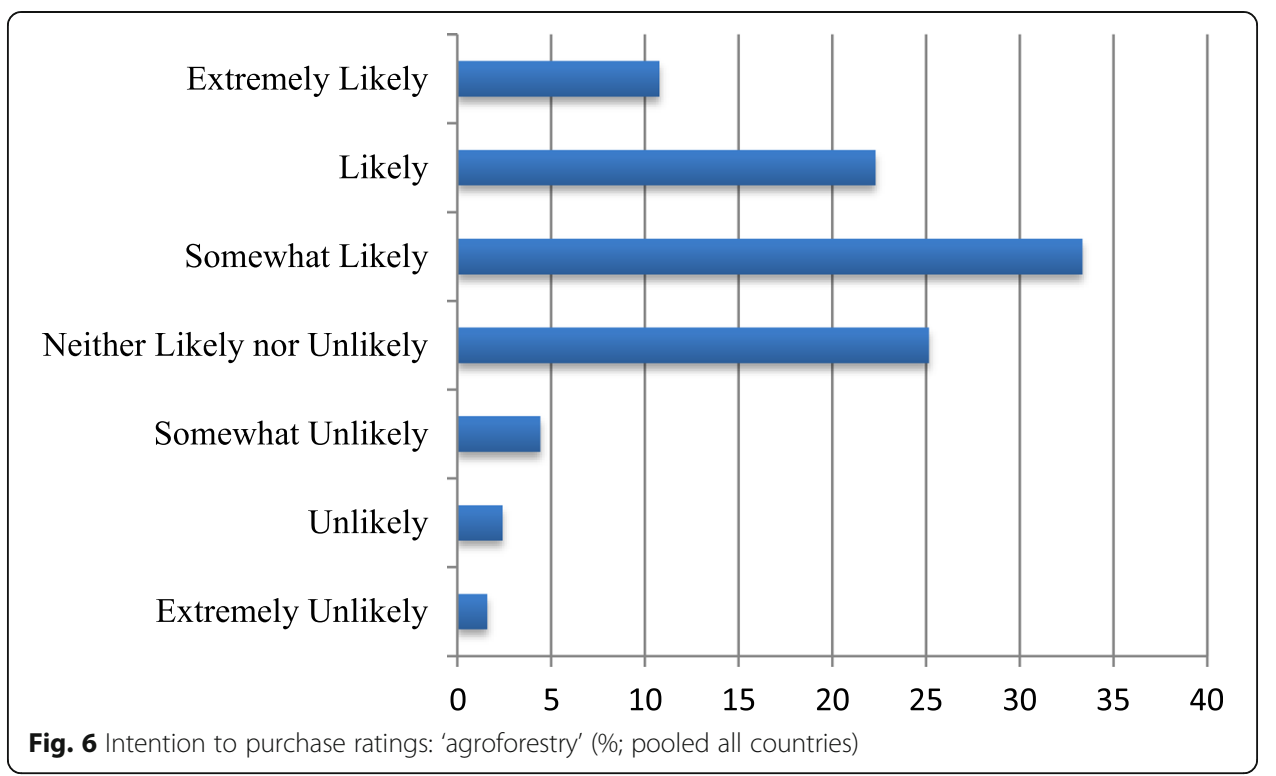

Table 15 gives the results for the means difference testing of attitude towards each of these innovative production practices across the countries. The results show that there are not many differences among these countries in terms of attitude towards the three alternative innovative production practices.

Table 15 gives the results for the means difference testing of attitude towards each of these innovative production practices across the countries. The results show that there are not many differences among these countries in terms of attitude towards the three alternative innovative production practices. The only statistically significant differences were the following:

- Finnish consumers appear much less favourable than all of the others to prolonged maternal feeding, followed by the UK consumers.

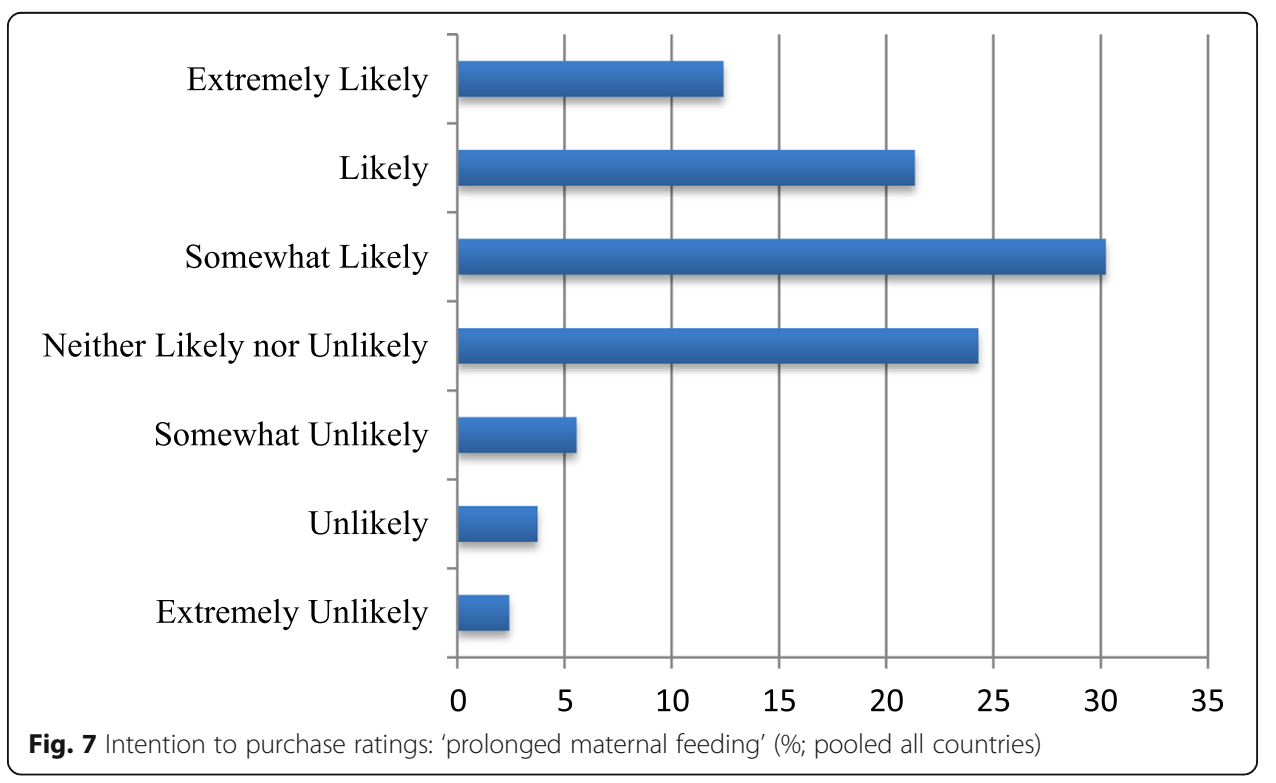




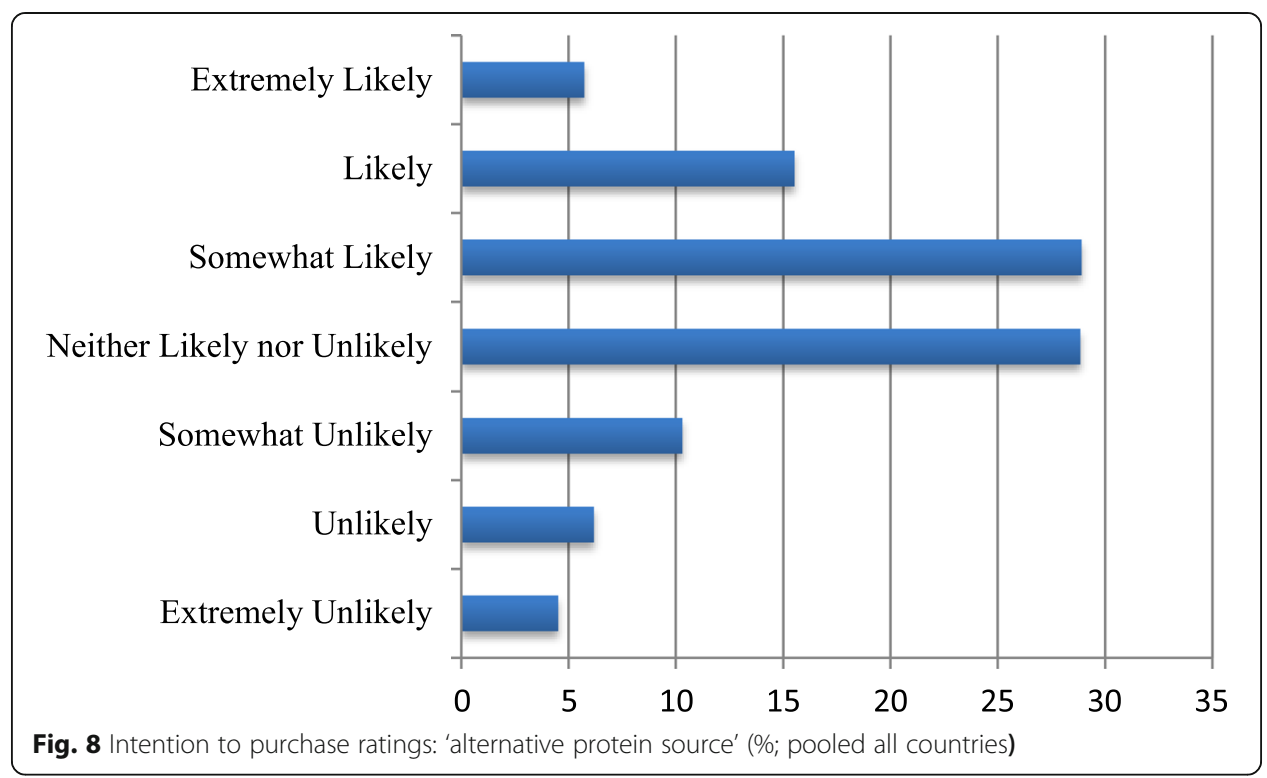

- Italian consumers were more favourable than all of the others to agroforestry, followed by the Finnish consumers. All of the consumers in the other countries do not differ in terms of their attitude towards agroforestry.

- There were no country differences in terms of consumer attitudes towards alternative protein sources.

These country variations are expected, but we can conclude that attitudes are, overall, relatively homogenous across Europe.

\section{Discussion}

\section{Explanatory power and testing of the hypotheses}

The models provided good insights into the formation of attitudes and purchase intentions towards dairy products obtained using these three production practices.

Hypothesis 1 was clearly supported. As we were simply measuring the attitudes towards these practices, this finding confirms the strength of the Bredahl (2001) and Chen (2008) purchase intention models.

Hypothesis 2 was partially supported, in the sense that perceived benefits appear to be strongly driving attitude, while given the nature of the proposed technological improvements, perceived risks did not have any role in our model.

Hypothesis 3 was supported, where the role of subjective norm in influencing intentions was confirmed for all of the production practices.

Table 12 Descriptive statistics for intention to purchase ratings (all countries)

\begin{tabular}{lll}
\hline Model & Mean & Standard deviation \\
\hline Agroforestry & $5.0^{\mathrm{a}}$ & 1.2 \\
Prolonged maternal feeding & $4.9^{\mathrm{a}}$ & 1.4 \\
Alternative protein sources & $4.4^{\mathrm{b}}$ & 1.4 \\
\hline
\end{tabular}

Values with different superscript letters are significantly different ( $p>0.01$; Bonferroni adjusted) 
Table 13 Pooled SEM model fit indices

\begin{tabular}{|c|c|c|c|c|c|c|c|c|}
\hline \multirow[t]{2}{*}{ Model } & \multirow[t]{2}{*}{$x^{2}$} & \multirow[t]{2}{*}{ df } & \multirow{2}{*}{$\begin{array}{l}P \\
\text { value }\end{array}$} & \multicolumn{3}{|c|}{ RMSEA } & \multirow{2}{*}{$\begin{array}{l}\text { SRMS } \\
\mathrm{R}\end{array}$} & \multirow[t]{2}{*}{ CFI } \\
\hline & & & & Value & $90 \% \mathrm{Cl}$ & Probability $(\leq 0.05)$ & & \\
\hline Agroforestry & 131.70 & 36 & $<0.001$ & 0.038 & $0.31-0.45$ & 0.997 & 0.023 & 0.988 \\
\hline Prolonged maternal feeding & 127.72 & 36 & $<0.001$ & 0.037 & $0.30-0.44$ & 0.999 & 0.021 & 0.990 \\
\hline Alternative protein source & 121.34 & 36 & $<0.001$ & 0.036 & $0.29-0.48$ & 0.999 & 0.020 & 0.990 \\
\hline
\end{tabular}

Hypothesis 4 referred to the relevance of moral norm as an antecedent of intention to purchase, and it was supported for two of the innovative production practices out of three.

The results of post hoc analysis allow the testing of Hypotheses 5 and 6 .

Regarding the former (hypothesis 5), occasional organic consumers appeared to have a more favourable attitude towards all of these innovations than non-organic consumers, while regular consumers were even more favourable (i.e. exhibited a higher mean difference). One significant exception was for alternative protein source, where regular consumers showed a lower positive attitude than occasional consumers. All of the differences in the means and standardised effects sizes (differences standardised in terms of standard deviation) were significant $(p<0.01)$.

We can conclude here that occasional organic consumers are, on average, about 0.24 of a standard deviation greater than non-consumers in terms of favourable attitude towards agroforestry, 0.18 of a standard deviation greater than non-consumers in terms of favourable attitude towards prolonged maternal feeding and 0.35 of a standard deviation greater than non-consumers in terms of favourable attitude towards alternative protein source.

Regular consumers were, on average, about 0.28 of a standard deviation greater than non-consumers in terms of favourable attitude towards agroforestry, 0.37 of a standard deviation greater than non-consumers in terms of favourable attitude towards

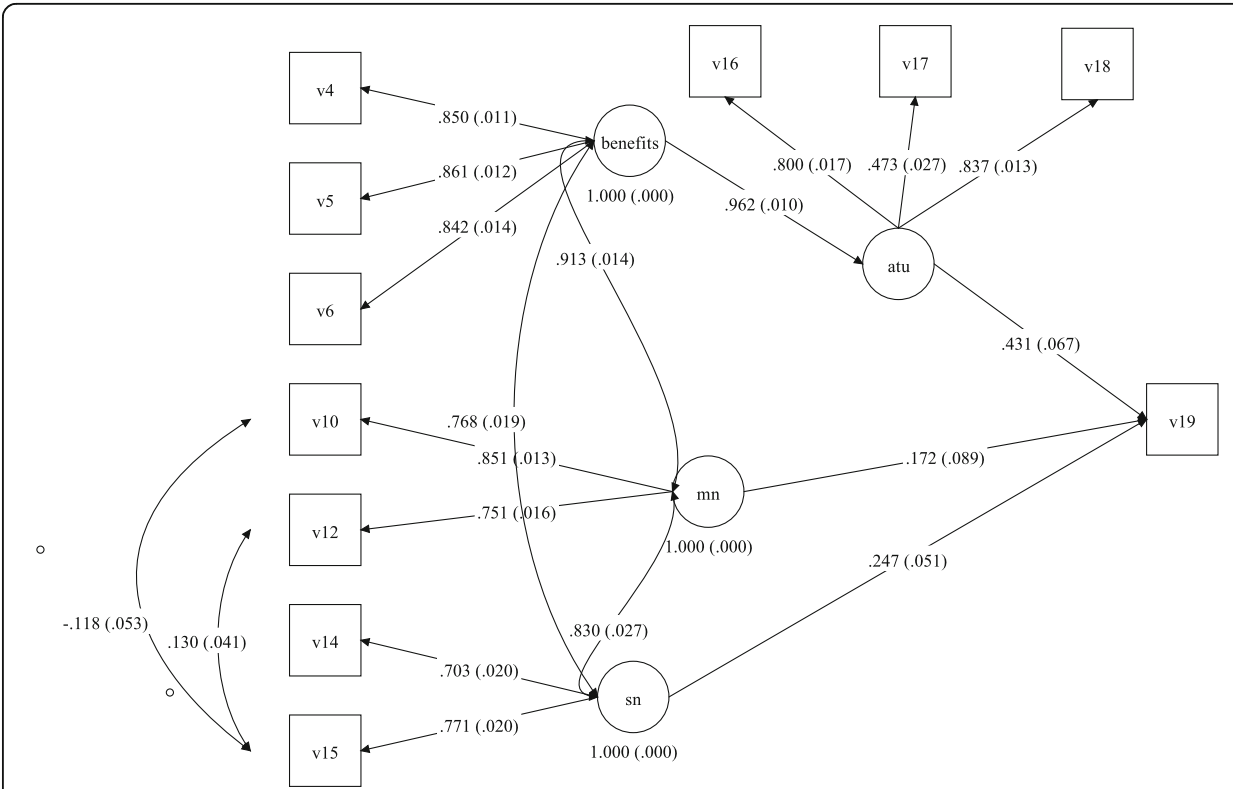

Fig. 9 Final pooled model for 'agroforestry'. Standardised parameter estimates are shown with associated standard errors in parentheses 


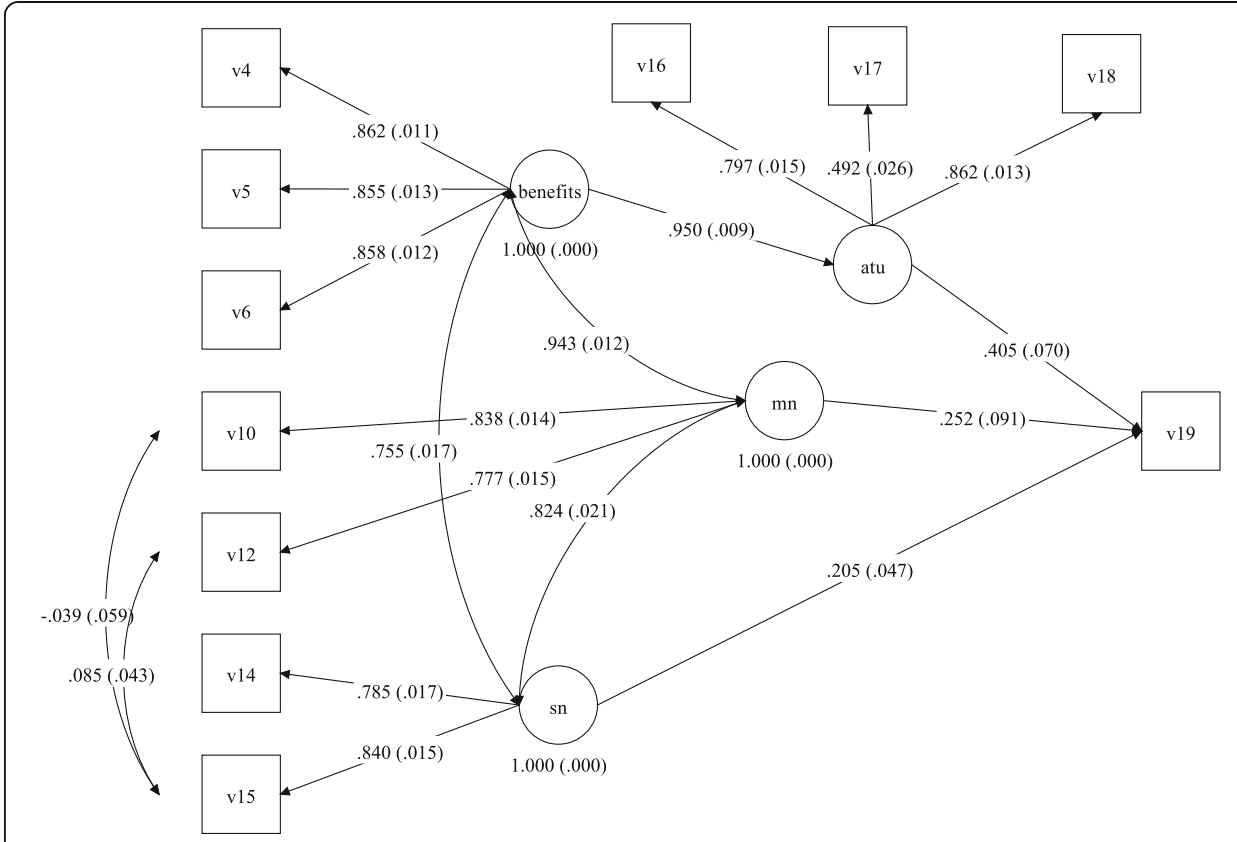

Fig. 10 Final pooled model for 'prolonged maternal feeding'. Standardised parameter estimates are shown with associated standard errors in parentheses

prolonged maternal feeding and 0.24 of a standard deviation greater than nonconsumers in terms of favourable attitude towards alternative protein source.

Hypothesis 5 was also not rejected. Together with hypothesis 4, this allowed us to conclude that the more value-driven consumers are, the more favourable they are towards these sustainable production practices.

For hypothesis 6, these data also favour a highly significant difference between women and men in terms of attitude towards all of the practices except alternative protein source. Women were, on average, 0.19 of a standard deviation greater than men in terms of favourable attitude towards agroforestry and 0.17 of a standard deviation greater than men in terms of favourable attitude towards prolonged maternal feeding.

\section{Conclusions}

This study examined how a number of socio-psychological constructs and personal characteristics affect consumer attitudes and intentions towards dairy products obtained through using three innovative and sustainable production practices: agroforestry, prolonged maternal feeding and alternative protein sources. Across all of these countries, prolonged maternal feeding was the production practice that showed the highest level of acceptance by consumers. The least accepted practice was alternative protein source for the feeding of dairy cows.

The following conclusions can be drawn from these data:

1. Prolonged maternal feeding was the most accepted practice by consumers. This strategy would clearly increase the production cost for dairy farmers by limiting the milk that is available for sale. Therefore, it might be a viable solution only if the farmers received adequate monetary compensation for potential losses. Further 


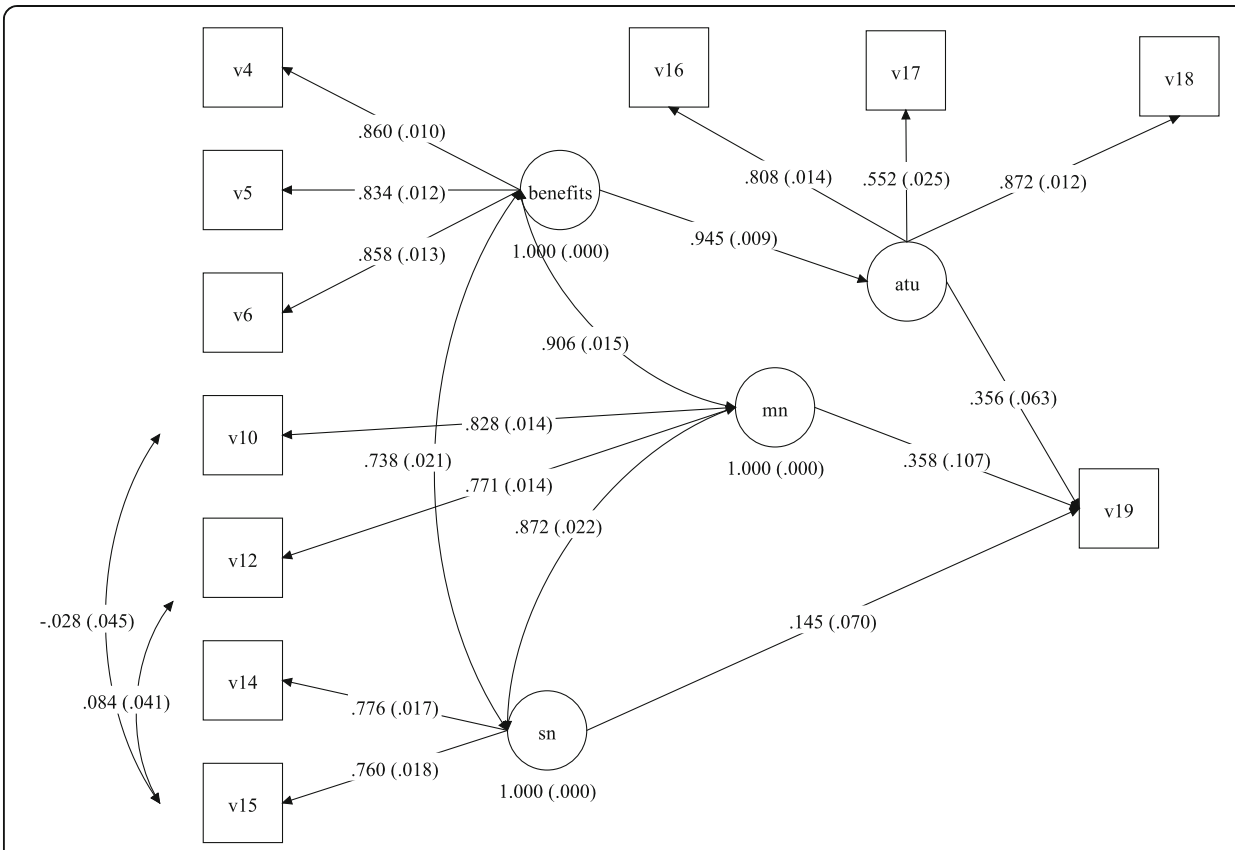

Fig. 11 Final pooled model for 'alternative protein source'. Standardised parameter estimates are shown with associated standard errors in parentheses

Table 14 Latent mean difference, variance and effect sizes for attitude-gender (reference: males) and experience (reference: non-organic) comparisons

\begin{tabular}{|c|c|c|c|c|c|}
\hline \multirow[t]{2}{*}{ Statistic/model } & \multicolumn{2}{|c|}{ Gender comparison (vs. M) } & \multicolumn{3}{|c|}{ Experience comparison (vs. NO) } \\
\hline & $\bar{M}$ & $\mathbf{F}$ & NO & 00 & OR \\
\hline \multicolumn{6}{|l|}{ Mean difference } \\
\hline Agroforestry & 0 & 0.185 & 0 & 0.233 & 0.29 \\
\hline Prolonged maternal feeding & 0 & 0.168 & 0 & 0.174 & 0.368 \\
\hline Alternative protein source & 0 & 0.073 & 0 & 0.354 & 0.25 \\
\hline \multicolumn{6}{|l|}{ Mean variance } \\
\hline Agroforestry & 1.029 & 0.993 & 0.978 & 0.879 & 1.123 \\
\hline Prolonged maternal feeding & 1.05 & 1.055 & 1.108 & 0.905 & 1.048 \\
\hline Alternative protein source & 1.127 & 1.175 & 1.05 & 1.066 & 1.29 \\
\hline \multicolumn{6}{|l|}{ Effect Size } \\
\hline Agroforestry & & 0.184 & & 0.240 & 0.284 \\
\hline Prolonged maternal feeding & & 0.164 & & 0.178 & 0.367 \\
\hline Alternative protein source & & 0.069 & & 0.352 & 0.237 \\
\hline \multicolumn{6}{|l|}{ Sample size $(n)$} \\
\hline Agroforestry & 759 & 1070 & 769 & 472 & 588 \\
\hline Prolonged maternal feeding & 727 & 1125 & 794 & 475 & 583 \\
\hline Alternative protein source & 799 & 1017 & 801 & 438 & 577 \\
\hline
\end{tabular}

Bold indicates significant differences/effect sizes $(p<0.05)$ 
Table 15 Latent mean difference, variance and effect sizes for attitude-country comparisons (reference country: AT)

\begin{tabular}{|c|c|c|c|c|c|c|}
\hline \multirow[t]{2}{*}{ Statistic/model } & \multicolumn{6}{|c|}{ Country comparison (vs. AT) } \\
\hline & AT & $\mathrm{BE}$ & DK & $\mathrm{FI}$ & IT & UK \\
\hline \multicolumn{7}{|l|}{ Mean difference } \\
\hline Agroforestry & 0 & -0.123 & 0.016 & 0.163 & 0.503 & 0.025 \\
\hline Prolonged maternal feeding & 0 & -0.111 & -0.154 & -0.332 & 0.092 & -0.188 \\
\hline Alternative protein source & 0 & -0.161 & 0.02 & 0.104 & 0.022 & -0.164 \\
\hline \multicolumn{7}{|l|}{ Mean variance } \\
\hline Agroforestry & 1.02 & 0.741 & 1.091 & 0.927 & 0.999 & 1.131 \\
\hline Prolonged maternal feeding & 1.022 & 0.915 & 0.933 & 1.055 & 1.189 & 1.191 \\
\hline Alternative protein source & 1.202 & 1.153 & 1.03 & 1.112 & 1.192 & 1.225 \\
\hline \multicolumn{7}{|l|}{ Effect Size } \\
\hline Agroforestry & & -0.131 & 0.016 & 0.165 & 0.501 & 0.024 \\
\hline Prolonged maternal feeding & & -0.113 & -0.156 & -0.326 & 0.087 & -0.179 \\
\hline Alternative protein source & & -0.155 & 0.020 & 0.101 & 0.021 & -0.155 \\
\hline \multicolumn{7}{|l|}{ Sample size $(n)$} \\
\hline Agroforestry & 306 & 297 & 296 & 300 & 329 & 301 \\
\hline Prolonged maternal feeding & 299 & 312 & 300 & 305 & 327 & 309 \\
\hline Alternative protein source & 300 & 292 & 297 & 299 & 329 & 299 \\
\hline
\end{tabular}

Bold indicates significant differences/effect sizes $(p<0.05)$

investigations into the willingness-to-pay associated to these practices are needed, although this is beyond the scope of the present study.

2. Alternative protein source appears not to be fully understood by consumers as a practice that might be of benefit to them. Indeed, consumer knowledge of the animal production process is very basic (Frewer et al. 2005; McEachern and Seaman 2005; Di Pasquale et al. 2014), and therefore, this result is not particularly surprising. One explanation might be that the consumers perceived the innovative practice as mainly of benefit to the farmers, as they might not have fully understood the importance in terms of food safety and traceability of reducing the outsourcing of protein by farmers.

3. Agroforestry appears to be of low interest for consumers. As a practice, it has different acceptance in different countries, given the differences in their dairy systems. If coupled with an approach that increases grazing and, more generally, favours grass-fed dairy systems, agroforestry might be an important practice that would appeal to both consumers and policymakers. It might also help in the pursuing of other societal goals (e.g. low-carbon sustainable production, use of forage that does not compete with human food production). Further investigation into the acceptance by other supply chain members is needed.

As a general conclusion, this study has shown that sustainable dairy farming practices that are not perceived as addressing relevant ethical concerns or producing easily perceivable societal benefits are not likely to be accepted by consumers. Given that organic dairy products are well accepted by consumers, who are ready to pay more for them, the proposed innovations are likely to be relevant only if they become part of organic best practices. 
A number of potential limitations can be identified here. First, this study was focussed on behavioural intention, rather than actual or hypothetical choice of products that were produced using the identified practices. While intention is a necessary condition, it is not a sufficient condition for actual consumer choice. Furthermore, actual choice implies not only acceptance, but also evaluation of consumer perceived costs to counter the benefits of the proposed innovations. A study on actual or hypothetical choice implies a different design and is left for future research.

\section{Appendix}

Information presented on the alternative production practices:

\section{Agroforestry}

(a) Integration of animals (i.e. cows, sheep) and trees on the same plot of land

(b) Innovation strengths/opportunities:

I. Enables production of wood, forage, livestock and fruit or nuts (depending on trees chosen) on the same plot of land, which improves farm revenue

II. Increases soil and plant biodiversity and carbon sequestration and reduces soil erosion

III. Trees offer shelter to grazing animals, which benefits animal welfare

(c) Innovation weaknesses/threats:

I. High initial financial investment for the purchase of trees and ongoing management input

II. Forage value of the leaves for animal nutrition is largely unknown.

III. Trees may be damaged by livestock that eat, step on or rub against them.

2. Prolonged maternal feeding

(a) Calves and lambs can suckle directly from their mothers (or a foster mother) for the first 3-5 months after they are born.

(b) Innovation strength/opportunities:

I. Maternal feeding provides natural immunity for the animals

II. Improvement in animal welfare, as animals are allowed to exhibit natural behaviour

III. Additional costs of buying milk replacer to feed the calves/lambs can be avoided.

(c) Innovation weaknesses/threats:

I. Provision is needed for changes in the housing/handling of both the mother and the offspring.

II. Separation causes mother and offspring stress as they have had time to develop a strong social bond.

III. Reduction in the amount of milk available to sell commercially during the calf/lamb suckling period

3. Alternative protein source

(a) Use of home-grown protein crops, such as lupins, beans and peas, as animal feed

(b) Innovation strength/opportunities: 
I. Reduces the amount of imported soya from outside the EU and therefore reduces the risk of contamination of the European food chain by genetically modified organisms

II. Cultivation of protein crops, such as field beans and peas, has a fundamental role in organic/low-input agriculture by improving soil fertility.

III. Farmers can produce animal feed on the farm and therefore avoid extra costs associated with third party supplies, logistics, delivery and handling.

(c) Innovation weaknesses/threats:

I. Limited research available to determine the effects of alternative proteins on dairy animal production and long-term impact on health and fertility

II. Protein content and biological value of local alternative protein crops are often lower than for soya.

III. Locally home-grown alternative proteins might be insufficient to fulfil year round demand of dairy farms, and therefore feed from external sources might still be required.

\title{
Acknowledgements
}

Not applicable.

\section{Authors' contributions}

All authors have read and approved the final manuscript. However, R. Zanoli wrote the 'Theoretical framework and hypotheses' and 'Methods' sections, S. Naspetti wrote the 'Results' section and S. Mandolesi wrote the 'Discussion' section. All other Authors contributed to the research design and data collection. The 'Introduction' and 'Conclusions' section are in common.

\section{Funding}

The authors gratefully acknowledge the financial support of the EU Commission for the research project 'Sustainable Organic and Low-Input Dairying' (EU FP7 SOLID). The views expressed here are not in any way attributable to the EU Commission but are solely the responsibility of the authors.

\section{Availability of data and materials}

The datasets generated and analysed during the current study are available in the Mendeley repository: https://doi. org/10.17632/24nbmf7bzz.2.

\section{Competing interests}

The authors declare that they have no competing interests.

\begin{abstract}
Author details
'Dipartimento di Scienze e Ingegneria della Materia, dell'Ambiente ed Urbanistica (SIMAU), Università Politecnica delle Marche, Via Brecce Bianche, 60131 Ancona, Italy. ${ }^{2}$ Department of Agricultural Economics, Faculty of Bioscience Engineering, Ghent University, B-9000 Gent, Belgium. ${ }^{3}$ Economic Research, Natural Resources Institute Finland (Luke), Koetilantie 5, 00790 Helsinki, Finland. ${ }^{4}$ Institute of Biological, Environmental and Rural Sciences (IBERS), Gogerddan Campus Aberystwyth University, Aberystwyth SY23 3EE, UK. ${ }^{5}$ Organic Research Centre, Elm Farm, Hamstead Marshall, Newbury, Berkshire RG20 OHR, UK. ${ }^{6}$ Dipartimento di Scienze Agrarie, Alimentari e Ambientali (D3A), Università Politecnica delle Marche, Via Brecce Bianche, 60131 Ancona, Italy.
\end{abstract}

Received: 9 February 2019 Revised: 17 December 2019 Accepted: 6 December 2020 Published online: 01 February 2021

\section{References}

Ajzen I (1991) The theory of planned behavior. Organ Behav Hum Decis Process 50:179-211. https://doi.org/10.1016/07495978(91)90020-T

Almli VL, Næs T, Enderli G et al (2011) Consumers' acceptance of innovations in traditional cheese. A comparative study in France and Norway. Appetite 57:110-120. https://doi.org/10.1016/j.appet.2011.04.009

Anderson JC, Gerbing DW (1988) Structural equation modeling in practice: a review and recommended two-step approach Psychol Bull 103:411-423

Anderson JC, Wachenheim CJ, Lesch WC (2006) Perceptions of genetically modified and organic foods and processes. AgBioForum 9:180-194

Arvola A, Vassallo M, Dean M et al (2008) Predicting intentions to purchase organic food: the role of affective and moral attitudes in the Theory of Planned Behaviour. Appetite 50:443-454. https://doi.org/10.1016/j.appet.2007.09.010

Bishop R (2006) Cheese innovation: market driven vs. regulatory standards. Aust J Dairy Technol 61:196-197

Bjorklund EA, Heins BJ, DiCostanzo A, Chester-Jones H (2014) Fatty acid profiles, meat quality, and sensory attributes of organic versus conventional dairy beef steers. J Dairy Sci 97:1828-1834. https://doi.org/10.3168/jds.2013-6984 
Bredahl L (2001) Determinants of consumer attitudes and purchase intentions with regard to genetically modified foods results of a cross-national survey. J Consum Policy 24:23-61. https://doi.org/10.1023/A:1010950406128

Chen M-F (2008) An integrated research framework to understand consumer attitudes and purchase intentions toward genetically modified foods. Br Food J 110:559-579. https://doi.org/10.1108/00070700810877889

Cheung GW, Rensvold RB (2002) Evaluating goodness-of-fit indexes for testing measurement invariance. Struct Equ Model A Multidiscip J 9:233-255. https://doi.org/10.1207/S15328007SEM0902

Cook AJ, Fairweather JR (2007) Intentions of New Zealanders to purchase lamb or beef made using nanotechnology. Br Food J 109:675-688

Davis FDF, Bagozzi RPR, Warshaw PPR (1992) Extrinsic and intrinsic motivation to use computers in the workplace. J Appl Soc Psychol 22:1111-1132. https://doi.org/10.1111/j.1559-1816.1992.tb00945.x

Dean M, Raats MM, Shepherd R (2008) Moral concerns and consumer choice of fresh and processed organic foods. J Appl Soc Psychol 38:2088-2107. https://doi.org/10.1111/j.1559-1816.2008.00382.x

Di Pasquale J, Nannoni E, Del Duca I et al (2014) What foods are identified as animal friendly by Italian consumers? Ital J Anim Sci 13:782-789. https://doi.org/10.4081/ijas.2014.3582

Dumont B, Groot JC, Tichit M (2018) Review: make ruminants green again - how can sustainable intensification and agroecology converge for a better future? Animal 12:210-212. https://doi.org/10.1017/S1751731118001350

Eurostat (2014a) Population by educational attainment level, sex, age and country of birth (\%) [edat Ifs 9912]. http://appsso. eurostat.ec.europa.eu/nui/show.do?dataset=edat_lfs_9912\&lang=en. Accessed 20 Sept 2019

Eurostat (2014b) Gini coefficient of equivalised disposable income - EU-SILC survey [ilc_di12]. http://appsso.eurostat.ec. europa.eu/nui/show.do?wai=true\&dataset=ilc_di12. Accessed 20 Sept 2019

Frewer $\mathrm{L}$, Kole A, van de Kroon SM, de Lauwere C (2005) Consumer attitudes towards the development of animal-friendly husbandry systems. J Agric Environ Ethics 18:345-367. https://doi.org/10.1007/s10806-005-1489-2

Grunert KG (2005) Consumer behaviour with regard to food innovations: quality perception and decisionmaking. In: Jongen WMF, Meulenberg MTG (eds) Innovation in agri-food systems: product quality and consumer. Wageningen Academic Publishers, Wageningen, pp 57-85

Grunert KG, La L, Poulsen JB et al (2001) Consumer perceptions of food products involving genetic modification — results from a qualitative study in four Nordic countries. Food Qual Prefer 12:527-542

Guerrero L, Guàrdia MD, Xicola J et al (2009) Consumer-driven definition of traditional food products and innovation in traditional foods. A qualitative cross-cultural study. Appetite 52:345-354. https://doi.org/10.1016/j.appet.2008.11.008

Ha-Brookshire Jung E (2011) Willingness to pay for socially responsible products: case of cotton apparel. J Consum Mark 28: 344-353. https://doi.org/10.1108/07363761111149992

Hancock GR, Mueller OR (eds) (2013) Structural equation modeling: a second course. Information Age Puublishing, Charlotte

Hermans F, Roep D, Klerkx L (2016) Scale dynamics of grassroots innovations through parallel pathways of transformative change. Ecol Econ 130:285-295. https://doi.org/10.1016/j.ecolecon.2016.07.011

Jordana J (2000) Traditional foods: challenges facing the European food industry. Food Research International, 33:147-152. https://doi.org/10.1016/50963-9969(00)00028-4

King WR, He J (2006) A meta-analysis of the technology acceptance model. Inf Manag 43:740-755. https://doi.org/10.1016/j. im.2006.05.003

Kline RB (2011) Principles and practice of structural equation modeling, 3rd edn. The guilford Press, New York

Kühne B, Vanhonacker F, Gellynck X, Verbeke W (2010) Innovation in traditional food products in Europe: do sector innovation activities match consumers' acceptance? Food Qual Prefer 21:629-638. https://doi.org/10.1016/j.foodqual.2010. 03.013

López-Mosquera N (2016) Gender differences, theory of planned behavior and willingness to pay. J Environ Psychol 45:165175. https://doi.org/10.1016/.j.envp.2016.01.006

Luce MF, Payne JW, Bettman JR (2000) Coping with unfavorable attribute values in choice. Organ Behav Hum Decis Process 81:274-299. https://doi.org/10.1006/obhd.1999.2872

Magnusson MK (2001) Attitudes towards organic foods among Swedish consumers. Br Food J 103:209-227. https://doi.org/ $10.1108 / 00070700110386755$

Mandolesi S, Nicholas P, Naspetti S, Zanoli R (2015) Identifying viewpoints on innovation in low-input and organic dairy supply chains: a Q-methodological study. Food Policy 54:25-34. https://doi.org/10.1016/j.foodpol.2015.04.008

Mazzocchi M, Lobb A, Traill WB, Cavicchi A (2008) Food scares and trust: a European study. 59:2-24. https://doi.org/10.1111/j. 1477-9552.2007.00142.x

McEachern MG, Seaman C (2005) Consumer perceptions of meat production: enhancing the competitiveness of British agriculture by understanding communication with the consumer. Br Food J 107:572-593. https://doi.org/10.1108/ 00070700510610986

Meade AW, Johnson EC, Braddy PW (2008) Power and sensitivity of alternative fit indices in tests of measurement invariance. J Appl Psychol 93:568-592. https://doi.org/10.5465/AMBPP.2006.27182124

Muthén LK, Muthén BO (2017) Mplus user's guide, 8th edn. Muthén \& Muthén, Los Angeles

Napolitano F, Braghieri A, Piasentier E et al (2010a) Effect of information about organic production on beef liking and consumer willingness to pay. Food Qual Prefer 21:207-212. https://doi.org/10.1016/j.foodqual.2009.08.007

Napolitano F, Braghieri A, Piasentier E et al (2010b) Cheese liking and consumer willingness to pay as affected by information about organic production. J Dairy Res 77:280-286. https://doi.org/10.1017/S0022029910000130

Nicholas PK, Mandolesi S, Naspetti S, Zanoli R (2014) Innovations in low input and organic dairy supply chains--what is acceptable in Europe? J Dairy Sci 97:1157-1167. https://doi.org/10.3168/jds.2013-7314

O'Connor E, Cowan C, Williams G et al (2006) Irish consumer acceptance of a hypothetical second-generation GM yogurt product. Food Qual Prefer 17:400-411. https://doi.org/10.1016/j.foodqual.2005.05.003

O'Connor EL, White KM (2010) Willingness to trial functional foods and vitamin supplements: the role of attitudes, subjective norms, and dread of risks. Food Qual Prefer 21:75-81. https://doi.org/10.1016/j.foodqual.2009.08.004

Olsen NV, Sijtsema SJ, Hall G (2010) Predicting consumers' intention to consume ready-to-eat meals. The role of moral attitude. Appetite 55:534-9. https://doi.org/10.1016/j.appet.2010.08.016. 
Onwezen MC, Bartels J (2011) Which perceived characteristics make product innovations appealing to the consumer? A study on the acceptance of fruit innovations using cross-cultural consumer segmentation. Appetite 57:50-58. https://doi. org/10.1016/j.appet.2011.03.011

Ottar S, Heide M, Calvo D, Toften K (2008) Explaining intention to consume a new fish product: a cross-generational and cross-cultural comparison. Food Qual Prefer 19:618-627. https://doi.org/10.1016/j.foodqual.2008.04.007

Ozcaglar-Toulouse N, Shiu E, Shaw D (2006) In search of fair trade: ethical consumer decision making in France. Int J Consum Stud 30:502-514. https://doi.org/10.1111/j.1470-6431.2006.00532.x

Padel S, Vaarst M, Zaralis K (2015) Supporting innovation in organic sgriculture: $s$ European perspective using experience from the SOLID project. Sustain Agric Res 4:32. https://doi.org/10.5539/sar.v4n3p32

Saba A, Messina F (2003) Attitudes towards organic foods and risk/benefit perception associated with pesticides. Food Qual Prefer 14:637-645. https://doi.org/10.1016/50950-3293(02)00188-X

Satorra A, Bentler PM (1994) Corrections to test statistics and standard errors in covariance structure analysis. In: von Eye A, Clogg CC (eds) Latent variables analysis: applications for developmental research. Sage Publications, Thousand Oaks, pp 399-419

Schösler H, de Boer J, Boersema JJ (2013) The organic food philosophy: a qualitative exploration of the practices, values, and beliefs of Dutch organic consumers within a cultural-historical frame. J Agric Environ Ethics 26:439-460. https://doi.org/ 10.1007/s10806-012-9392-0

Scollan N, Padel S, Halberg N et al (2017) Organic and low-input dairy farming: avenues to enhance sustainability and competitiveness in the EU. EuroChoices 16:40-45. https://doi.org/10.1111/1746-692X.12162

Sodano V, Gorgitano MT, Verneau F, Vitale CD (2016) Consumer acceptance of food nanotechnology in Italy. Br Food J 118: 714-733. https://doi.org/10.1108/BFJ-06-2015-0226

Tung FC, Chang SC, Chou CM (2008) An extension of trust and TAM model with IDT in the adoption of the electronic logistics information system in HIS in the medical industry. Int J Med Inform 77:324-335. https://doi.org/10.1016/j. ijmedinf.2007.06.006

Ureña F, Bernabéu R, Olmeda M (2008) Women, men and organic food: differences in their attitudes and willingness to pay. A Spanish case study. Int J Consum Stud 32:18-26. https://doi.org/10.1111/j.1470-6431.2007.00637.x

Vanhonacker F, Kühne B, Gellynck X et al (2013) Innovations in traditional foods: impact on perceived traditional character and consumer acceptance. Food Res Int 54:1828-1835. https://doi.org/10.1016/j.foodres.2013.10.027

Venkatesh, Morris MG, Davis GB, Davis FD (2003) User acceptance of information technology: Toward a unified view. MIS Q 27:425-478. https://doi.org/10.2307/30036540.

Verdurme A, Gellynck X, Viaene J (2003) Consumers and new technologies: the case of GM food. Int J Biotechnol 5:439-453

Vermeir I, Verbeke W (2007) Sustainable food consumption among young adults in Belgium: theory of planned behaviour and the role of confidence and values. 4:0-11. https://doi.org/10.1016/j.ecolecon.2007.03.007

Zanoli R, Naspetti S (2002) Consumer motivations in the purchase of organic food. Br Food J 104:643-653. https://doi.org/10. $1108 / 00070700210425930$

Zhu Q, Li Y, Geng Y, Qi Y (2013) Green food consumption intention, behaviors and influencing factors among Chinese consumers. Food Qual Prefer 28:279-286. https://doi.org/10.1016/j.foodqual.2012.10.005

\section{Publisher's Note}

Springer Nature remains neutral with regard to jurisdictional claims in published maps and institutional affiliations.

\section{Submit your manuscript to a SpringerOpen ${ }^{\circ}$ journal and benefit from:}

- Convenient online submission

- Rigorous peer review

- Open access: articles freely available online

High visibility within the field

- Retaining the copyright to your article

Submit your next manuscript at $\boldsymbol{s p r i n g e r o p e n . c o m ~}$ 